\title{
Oxidative and endoplasmic reticulum stress in $\beta$-cell dysfunction in diabetes
}

\author{
Sumaira Z Hasnain ${ }^{1}$, Johannes B Prins ${ }^{2}$ and Michael A McGuckin ${ }^{1}$ \\ 'Immunity, Infection and Inflammation Program, Mater Research Institute, Translational Research Institute, \\ University of Queensland, 37 Kent Street, Woolloongabba, Brisbane, Queensland 4102, Australia \\ ${ }^{2}$ Metabolic Diseases Program, Mater Research Institute, The University of Queensland, Translational Research \\ Institute, 37 Kent Street, Woolloongabba, Brisbane, Queensland 4102, Australia
}

\author{
Correspondence \\ should be addressed \\ to M A McGuckin \\ Email \\ michael.mcguckin@ \\ mater.uq.edu.au
}

\begin{abstract}
The inability of pancreatic $\beta$-cells to make sufficient insulin to control blood sugar is a central feature of the aetiology of most forms of diabetes. In this review we focus on the deleterious effects of oxidative stress and endoplasmic reticulum (ER) stress on $\beta$-cell insulin biosynthesis and secretion and on inflammatory signalling and apoptosis with a particular emphasis on type 2 diabetes (T2D). We argue that oxidative stress and ER stress are closely entwined phenomena fundamentally involved in $\beta$-cell dysfunction by direct effects on insulin biosynthesis and due to consequences of the ER stress-induced unfolded protein response. We summarise evidence that, although these phenomenon can be driven by intrinsic $\beta$-cell defects in rare forms of diabetes, in T2D $\beta$-cell stress is driven by a range of local environmental factors including increased drivers of insulin biosynthesis, glucolipotoxicity and inflammatory cytokines. We describe our recent findings that a range of inflammatory cytokines contribute to $\beta$-cell stress in diabetes and our discovery that interleukin 22 protects $\beta$-cells from oxidative stress regardless of the environmental triggers and can correct much of diabetes pathophysiology in animal models. Finally we summarise evidence that $\beta$-cell dysfunction is reversible in T2D and discuss therapeutic opportunities for relieving oxidative and ER stress and restoring glycaemic control.
\end{abstract}

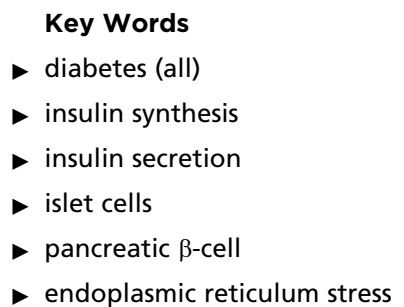

Key Words

- diabetes (all)

- insulin synthesis

- insulin secretion

- endoplasmic reticulum stress

\section{Introduction}

Diabetes is a spectrum of chronic disorders affecting close to 400 million people worldwide. Although the aetiology differs in the three main types of diabetes - type 1 diabetes (T1D), T2D and gestational diabetes - all feature the inability of the pancreatic $\beta$-cells to produce enough effective insulin to maintain glycaemic control. This review will explore the mechanisms by which insulin biosynthesis and secretion is impaired, focussing on the role of oxidative and endoplasmic reticulum (ER) stress in $\beta$-cell dysfunction in T2D. We first overview insulin biosynthesis and secretion, summarise the features of progression of diabetes. We then detail the significance of oxidative and ER stress in $\beta$-cell homeostasis and dysfunction, describe the drivers of stress, detail our new discovery of a previously unrecognised immune factor that protects $\beta$-cells from stress and, finally, address some key questions of importance to deepening our understanding of $\beta$-cell dysfunction and seeking effective therapeutic approaches.

Published by Bioscientifica Ltd. 


\section{Introduction to insulin biosynthesis and secretion}

Pancreatic $\beta$-cells are specifically designed to sense glucose fluctuations and, in response, release the hormone insulin that drives glucose uptake in the liver, muscle and fat, thus normalising blood glucose. Insulin also has a diverse range of other related and unrelated functions including reducing hepatic gluconeogenesis both directly and via suppression of glucagon secretion and suppressing appetite via a direct effect on hypothalamic neurones (Konner et al. 2007, Boucher et al. 2014).

The requirements for insulin biosynthesis mean that the secretory pathway in each $\beta$-cell is estimated to produce around one million molecules of insulin every minute (Scheuner \& Kaufman 2008). After translation, the preproinsulin polypeptide enters the ER, where it is folded in an oxidizing environment allowing for formation of three intramolecular disulfide bonds. A subsequent cleavage event in the ER forms proinsulin, which is then transported to the Golgi and packed into secretory granules. Proinsulin is a contiguous peptide with three intramolecular disulphide bonds; however, within the secretory granules proinsulin is proteolytically cleaved initially by prohormone convertase 1 or prohormone convertase 2, and then C-terminal basic residues are removed by carboxypeptidase E. Cleavage results in mature insulin consisting of the $\mathrm{B}$ and $\mathrm{A}$ chains held together by disulfide bonds plus the C-peptide that is co-secreted with insulin and has distinct biological effects. The importance of decreased proteolytic processing of insulin in T2D is discussed later in the review.

$\beta$-cell insulin secretion, depicted schematically in Fig. 1, is regulated by sensing glucose at physiological concentrations via the membrane glucose transporter GLUT2, which transports glucose into $\beta$-cells (Uldry \& Thorens 2004). Glucokinase then rapidly and efficiently phosphorylates the glucose to glucose-6-phosphate (Lynedjian 2009), which then enters the glycolytic pathway to produce pyruvate, which enters the mitochondrial Krebs cycle to produce ATP. $\beta$-cell ATP production, therefore, is reflective of the concentration of glucose in the blood (Jensen et al. 2008, Muoio \& Newgard 2008).

The membrane Kir6.2 $\mathrm{Na}^{+} / \mathrm{K}^{+}$ATPase channel maintains a relatively high intracellular concentration of $\mathrm{K}^{+}$, and $\beta$-cells use this gradient as a key step in the pathway of glucose-stimulated insulin secretion (GSIS). Increasing ATP levels in response to glucose closes the ATP-dependent $\mathrm{K}^{+}$channel resulting in a depolarization of the plasma membrane, which in turn activates a voltage-dependent $\mathrm{Ca}^{2+}$ channel. Consequently, the influx of $\mathrm{Ca}^{2+}$ stimulates preformed insulin vesicles to fuse with the plasma membrane and release their contents into the bloodstream, thereby resulting in insulin secretion commensurate with the increase in extracellular

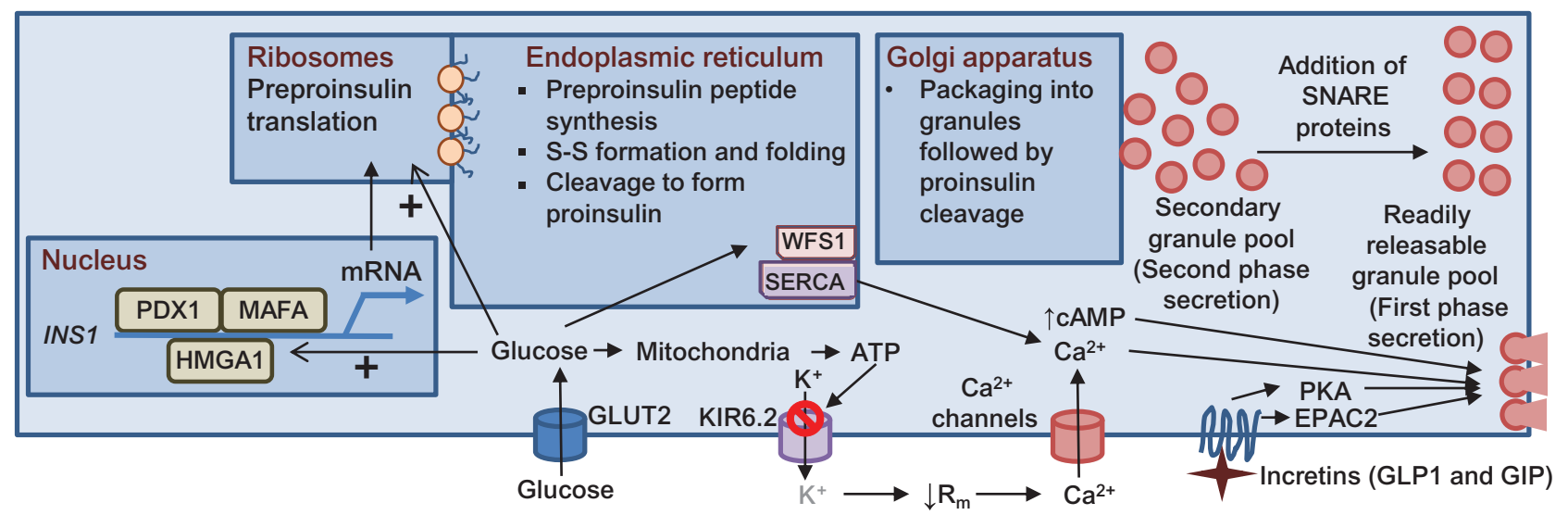

\section{Figure 1}

Major determinants of $\beta$-cell insulin biosynthesis and secretion. Insulin is synthesised in the secretory pathway and secretion is regulated by the concentration of extracellular glucose, which is taken up by the GLUT2 transporter and drives ATP production and closure of the KIR6.2 $\mathrm{K}^{+}$ channel. This in turn leads to the depolarisation and influx of $\mathrm{Ca}^{2+}$, which drives the secretion of insulin granules. Insulin secretion is further boosted by incretin-receptor-mediated activation of protein kinase A (PKA) and EPAC. Wolfram syndrome 1 (WFS1) is a negative regulator of the $\mathrm{ER} \mathrm{Ca}^{2+}$ pump SERCA, thereby potentiating the release of $\mathrm{Ca}^{2+}$ from the endoplasmic reticulum (ER) in response to glucose. In response to glucose stimulation, the first phase of insulin secretion involves mature granules ready for secretion and held near the $\beta$-cell membrane, and later secretion involves mobilisation of a secondary granule pool. High intracellular glucose also drives the increased translation and transcription of insulin, ensuring the replacement of secreted insulin. http://jme.endocrinology-journals.org DOI: 10.1530/JME-15-0232 (c) 2016 Society for Endocrinology Printed in Great Britain
Published by Bioscientifica Ltd 
glucose (Jensen et al. 2008, Muoio \& Newgard 2008). Two mechanistically defined pools of insulin granules are found within the cell: a readily releasable pool close to the plasma membrane in which granules contain the SNARE proteins and other facilitators of exocytosis and a reserve pool lacking these factors. These distinct pools of vesicles are thought to account for the biphasic release of insulin. The first phase is fast and of short duration, due to the release of the readily releasable pool of insulin vesicles, and the second phase is more sustained and of longer duration, resulting from the reserve pool of insulin vesicles (Wang \& Thurmond 2009, Seino et al. 2011).

Although glucose is the major determinant of insulin secretion, GSIS is also potentiated by other factors, including regulation via other islet secretory cells and the intestinal tract. Glucagon-like peptide 1 (GLP1) and glucose-dependent insulinotropic polypeptide (GIP) are peptides secreted by islet $\alpha$ cells and intestinal enteroendocrine cells that, among their many roles, stimulate $\beta$-cell insulin secretion via G-protein coupled receptors (Nauck 2009). These hormones, known as incretins, ensure that a glucose load passing through the digestive tract produces greater insulin secretion than an i.v. glucose load, thereby potentiating postprandial insulin secretion (Nauck 2009). Activation of the GLP1 receptor activates adenylate cyclase generating cAMP, which activates protein kinase A (PKA), leading to phosphorylation events that mediate insulin secretion (Doyle \& Egan 2007). cAMP also activates guanine nucleotide exchange factors Epac1 and Epac2, which facilitate $\mathrm{Ca}^{2+}$ release from the ER (Doyle \& Egan 2007). In contrast, GIP activates ATP-dependent $\mathrm{K}^{+}$ channels similarly to the glucose-stimulated pathway (Miki et al. 2005). More recently, it has become recognised that other circulating factors can modulate insulin release via $\beta$ cell G-protein coupled receptors. Examples include circulating fatty acids as ligands for GPR40 (Itoh et al. 2003) and GPR119 (Soga et al. 2005).

While GSIS temporarily reduces the number of stored insulin granules, particularly the mature granules, glucose and the incretins also stimulate insulin biosynthesis to replenish the granules between meals. Several transcription factors that regulate insulin transcription are glucose sensitive, including PDX1, MAFA and HMGA1, and this is enhanced by cAMP and PKA activation (Andrali et al. 2008, Arcidiacono et al. 2014, Rutter et al. 2015). In addition to the stimulation of insulin gene transcription, glucose also stimulates insulin translation. The effect of glucose stimulation on insulin translation is both rapid and potent, with a tenfold increase in insulin biosynthesis within 20 min of a glucose stimulus (Wicksteed et al. 2007).
Thus, insulin secretion and biosynthesis are highly co-regulated processes that respond to both increasing blood glucose and signals from the intestinal tract.

\section{The complex aetiology of T2D}

T2D is typically a gradually progressive disease that most often, but not always, occurs in the context of obesity and declining responsiveness to insulin in target tissues (insulin resistance). Whereas most obese individuals develop insulin resistance, only a proportion of these individuals develop T2D. While insulin resistance and $\beta$-cell dysfunction are an intrinsically linked phenomenon, several lines of evidence, including genetic linkages from genome-wide association studies, have firmly focussed attention on the $\beta$-cell as the critical primary contributor to hyperglycaemia in T2D (Ashcroft \& Rorsman 2012, Rosengren et al. 2012). In fact, development of therapeutics that address $\beta$-cell dysfunction is regarded by the pharmaceutical industry as the number one unmet need in T2D. Obese insulin-resistant individuals who do not develop diabetes manage to increase $\beta$-cell insulin production sufficiently to overcome the declining responsiveness in peripheral tissues. However, many individuals go through progressive phases of declining glycaemic control beginning with mild hyperglycaemia classified as prediabetes. Prediabetes and the early phases of diabetes are characterised by increasing, rather than decreasing, serum insulin and a progressive increase in serum proinsulin. Further progression of diabetes is accompanied by an increasing ratio of serum proinsuli$\mathrm{n}$ :insulin and declining insulin secretion in response to glucose challenge. Importantly, glucose challenges show that first phase insulin secretion from the mature secretion-ready granules is the first to decline as diabetes progresses (Seino et al. 2011). The complexity of insulin biosynthesis and release means that there are many potential contributors to defects in insulin release, and these factors, particularly those associated with $\beta$-cell oxidative and ER stress, are a major focus of this review.

\section{Oxidative and ER stress in $\beta$-cell dysfunction}

We argue that $\beta$-cell oxidative stress and ER stress are integral interconnected pathological features in T2D, contributing to aberrant insulin biosynthesis and secretion, immune activation and $\beta$-cell apoptosis (depicted schematically in Fig. 2). Oxidative stress occurs due to excess production or inadequate disposal of reactive oxygen species (ROS) and reactive nitrogen species (RNS)

Published by Bioscientifica Ltd. 


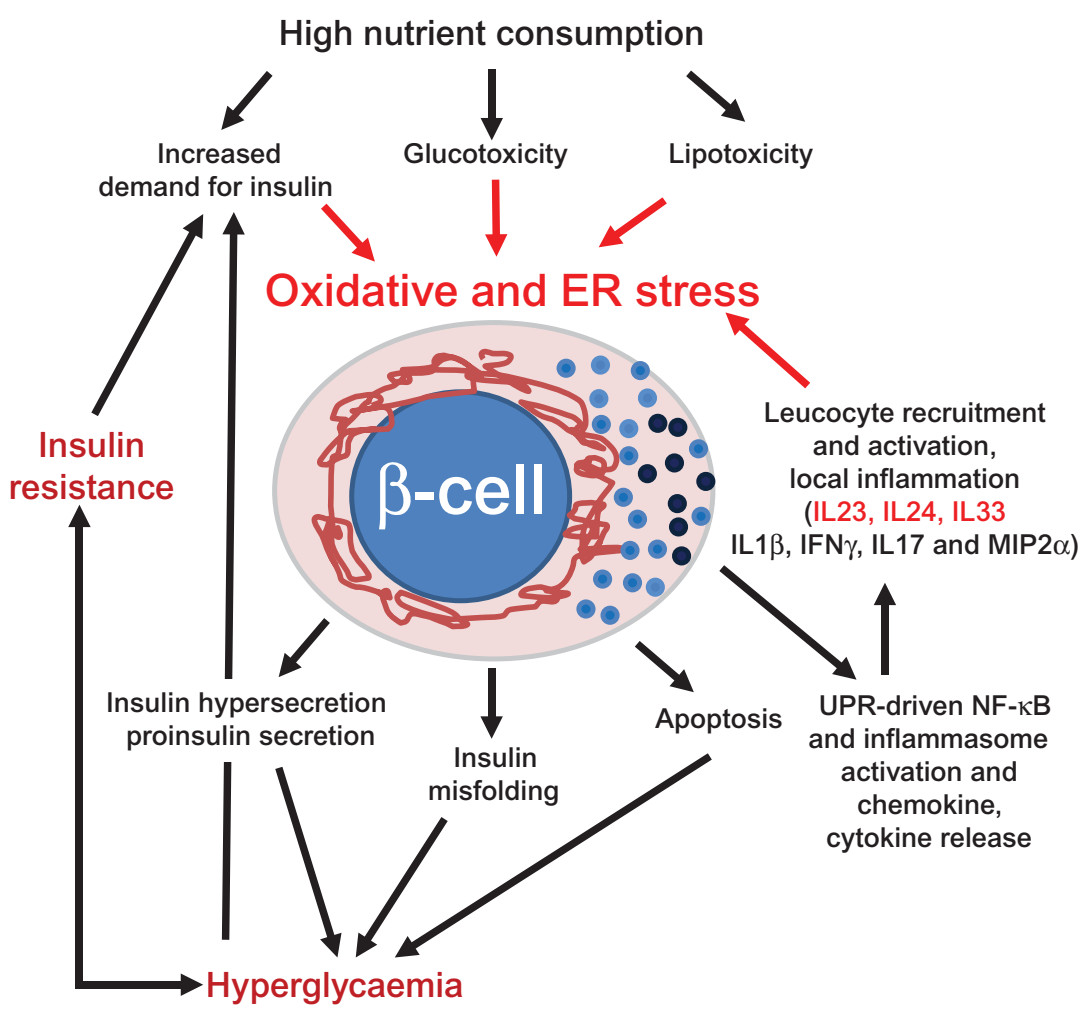

\section{Figure 2}

Schematic representation of the cycle of pancreatic islet endoplasmic reticulum (ER) stress and inflammation, which develops in diabetes, and its effects on glucose homeostasis. In obesity and the early stages of diabetes, high nutrient intake leads to increasing demands for insulin production and the development of mild insulin resistance and hyperglycaemia. In response, pancreatic $\beta$-cells increase the biosynthesis of insulin, which results in mild oxidative stress and ER stress, exacerbated by increases in circulating glucose and lipids, particularly non-esterified fatty acids. Oxidative stress and ER stress initiate chemokine production, and chemokines begin to activate inflammatory cells in the pancreatic islet microenvironment. With prolonged high nutrient intake, insulin resistance in the peripheral tissues continues to rise, requiring more insulin synthesis

that can have multiple deleterious effects on cellular metabolism. ER stress occurs when proteins in the secretory pathway misfold during biosynthesis, and the ensuing unfolded protein response (UPR) in $\beta$-cells can reduce insulin transcription and translation (Walter \& Ron 2011) and initiate inflammation and apoptosis (Hasnain et al. 2012, Eizirik et al. 2013). Oxidative and ER stress are closely entwined phenomena because oxidative stress can induce protein misfolding by disturbing the ER redox state and disrupting disulphide bond formation, and protein misfolding itself leads to the production of ROS (Cao \& Kaufman 2014). Thus, a deleterious cycle of $\beta$-cell dysfunction involving oxidative and ER stress, impaired secretory pathway function, $\beta$-cell apoptosis and local islet inflammation can progressively and secretion. $\beta$-cells develop increased oxidative and ER stress and chemokine release increases. Activated inflammatory cells produce cytokines that further drive oxidative and ER stress and disturb $\beta$-cell secretory pathway function. Activation of the unfolded protein response by acute ER stress suppresses insulin biosynthesis and secretion. However, in the chronic $\beta$-cell ER stress and islet inflammation seen in early diabetes, insulin synthesis is increased but perturbed, leading to the secretion of proinsulin, increasing the proinsulin:insulin ratio in blood impairing insulin receptor signalling and exacerbating hyperglycaemia. As diabetes progresses, insulin production falls and $\beta$-cell apoptosis increases, driving further defective glycaemic control.

develop in T2D (Donath et al. 2013, Eizirik et al. 2013, Montane et al. 2014). Although $\beta$-cell oxidative and ER stress are well-accepted phenomena in a range of different animal models of T1D and T2D, unfortunately, the direct evidence from human disease is relatively scant and therefore less compelling (Marchetti et al. 2007, Donath et al. 2009, Cnop et al. 2012, Marhfour et al. 2012, Tersey et al. 2012). However, one feature of human diabetic islets is an accumulation of $\beta$-amyloid, and this phenomenon has been linked with oxidative stress and apoptosis, in the absence of ER stress (Hull et al. 2009, Zraika et al. 2009).

\section{Oxidative stress}

ROS and RNS comprise a variety of molecules that can be found in $\beta$-cells including free radicals, such as nitric oxide

Published by Bioscientifica Ltd 
$\left(\mathrm{NO}{ }^{*}\right)$, superoxide $\left(\mathrm{O}_{2}^{-}\right)$and the hydroxyl radical $\left(\mathrm{OH}^{*}\right)$, non-radicals such as hydrogen peroxide $\left(\mathrm{H}_{2} \mathrm{O}_{2}\right)$, or anions such as superoxide $\left(\mathrm{O}_{2}^{-}\right)$and peroxynitrite $\left(\mathrm{ONOO}^{-}\right)$ (Lenzen 2008, Newsholme et al. 2012, Cao \& Kaufman 2014, Keane et al. 2015). ROS and RNS can be products of mitochondrial metabolism or can be produced in the cytoplasm, for example, by the enzymes NADPH oxidase and induced nitrogen oxide synthase (iNOS). Different ROS and RNS can also react; for example, $\mathrm{NO}^{-}$and $\mathrm{O}_{2}^{-{ }^{-}}$can react to produce $\mathrm{ONOO}^{-}$, which is a very potent ER stress inducer. To regulate intracellular ROS and RNS, cells produce a range of detoxifying enzymes, and the balance between production and detoxification therefore determines intracellular ROS and RNS concentrations. Because of their high biosynthetic load and requirement for oxygen, $\beta$-cells are considered to be very sensitive to the overproduction of ROS and RNS, and oxidative stress is considered an important element of $\beta$-cell dysfunction in T2D and of $\beta$-cell depletion in T1D (Lenzen 2008, Newsholme et al. 2012, Cao \& Kaufman 2014, Keane et al. 2015). In addition to causing ER stress, oxidative stress has multiple deleterious effects on $\beta$-cell function, including suppression of insulin transcription (Kaneto \& Matsuoka 2015). However, it has been proposed that the production of some ROS is necessary for signalling within $\beta$-cells and normal biosynthetic and secretory function (Jezek et al. 2012). The triggers for $\beta$-cell oxidative stress are discussed in detail later in the review; below we focus on the consequences of ER stress for $\beta$-cell dysfunction.

\section{ER stress and the UPR}

$\beta$-cells are professional secretory cells and therefore possess a well-developed ER to handle the large biosynthetic load. Some protein misfolding in the ER is inevitable, and misfolding multiplies with increasing protein complexity, so the ER has well-developed mechanisms to recognise and remove misfolded proteins that would otherwise accumulate. Proinsulin is quite susceptible to misfolding and estimates are that around $20 \%$ of proinsulin misfolds in a healthy $\beta$-cell, equating to around 200000 misfolded proinsulin molecules every minute (Sun et al. 2015). However, the condition known as ER stress occurs only when protein misfolding increases beyond threshold levels, triggering a suite of signalling and transcriptional events known collectively as the UPR, which is engaged to restore ER homeostasis. In normal secretory cells there is likely to be an almost continuous low level of UPR activation, and in fact, two of the UPR transcription factors, X-box-binding protein 1 (XBP1) and activating transcription factor 6 (ATF6), have roles in ER biogenesis to enhance biosynthetic capacity, which is critical as secretory cells differentiate (Calfon et al. 2002, Sriburi et al. 2007, Bommiasamy et al. 2009). The episodic nature of insulin secretion and, to a lesser extent, biosynthesis probably results in episodic variation in this baseline UPR activation, although this has not been closely studied. UPR activation is primarily regulated by a heatshock protein/chaperone, GRP78 or BiP, which normally associates with and keeps inactive the three major ER-resident UPR pathway initiating molecules IRE1, PERK and ATF6. GRP78 engages with the exposed hydrophobic domains of misfolded proteins and, in the process, disassociates from IRE1, PERK and ATF6, triggering their activation and the downstream UPR, which is depicted schematically in Fig. 3.

There are three main functional outcomes of the UPR: decreased translation, restoration of protein folding and ER-associated degradation (ERAD) of misfolded proteins (Walter \& Ron 2011). In addition to altering the ER, the UPR can have wider influences, and prolonged or severe ER stress can induce inflammation, autophagy and apoptosis. The ultimate goal of the UPR is to restore ER protein biosynthesis, but paradoxically, one initial step is a PERK-mediated phosphorylation of eIF $2 \alpha$, which suppresses translation of secretory proteins to relieve ER load (Harding et al. 1999). Thus, the physiological response mechanism, while protecting the secretory cell from further ER stress, can have adverse physiological effects that, in the case of $\beta$-cell ER stress, would be a net reduction in insulin production and, hence, disposition to hyperglycaemia. Although this is a classically studied consequence of acute ER stress, the inhibition of translation cannot be maintained in secretory cells without ablating their primary function, and chronic ER stress, at least in the early phases of diabetes, is associated with hyperinsulinaemia, consistent with a net increase in insulin secretion across all $\beta$-cells. In addition to the inhibition of translation, PERK drives the expression of multiple genes by activation of transcription factors including ATF4 and CCAAT-enhancer-binding protein homologous protein (CHOP, also known as GADD34; Schroder \& Kaufman 2006). CHOP can be a stimulus for ER stress-induced apoptosis in multiple cell types, including $\beta$-cells (Marciniak et al. 2004). Deletion of CHOP can result in a hypo-oxidizing environment and protects cells from ER stress-induced apoptosis (Oyadomari et al. 2002, Marciniak et al. 2004).

IRE $1 \alpha$ is a ubiquitously expressed endoribonuclease that is activated by disengagement with GRP78 and direct

Published by Bioscientifica Ltd 


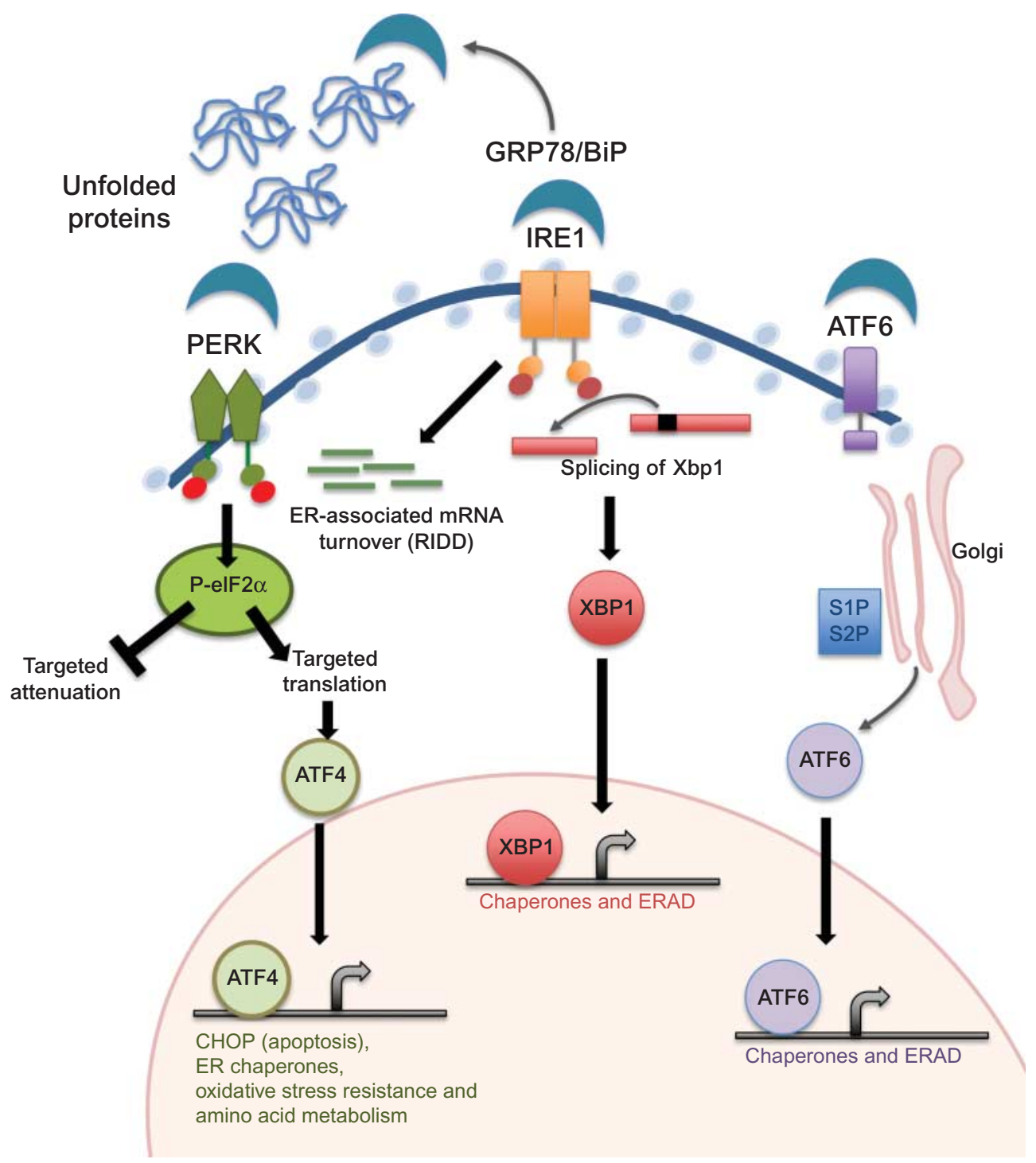

\section{Figure 3}

Key components of the unfolded protein response (UPR). The three major arms of the UPR are controlled by regulatory proteins located in the endoplasmic reticulum (ER) membrane: protein kinase-R-like ER kinase (PERK), inositol-requiring enzyme 1 (IRE1 $\alpha$ ) and activating transcription factor 6 (ATF6). Under homeostatic conditions, these proteins are bound by the chaperone GRP78 (also known as BiP). Protein misfolding and ER stress leads to the sequestration of Grp78 to the exposed hydrophobic domains of misfolded proteins and the activation of PERK, IRE1 $\alpha$ and ATF6. PERK is a kinase that phosphorylates eukaryotic translation initiation factor 2 alpha (elF2 $\alpha$ ) resulting in the selective inhibition of the translation of secretory pathway proteins, while promoting the translation of the transcription factor ATF4, that activates genes including C/EBP-homologous protein

recognition of misfolded proteins (Kimata et al. 2007, Promlek et al. 2011). IRE1 $\alpha$ primarily targets the XBP1 mRNA, splicing of which results in the translation of the spliced-XBP1 transcription factor that drives the expression of ER chaperones, components of ERAD, and
(CHOP), which drives apoptosis. IRE $1 \alpha$ is an endoribonuclease that splices the mRNA transcript for X-box-binding protein 1 (XBP1), which then encodes a transcription factor that induces the expression of genes encoding proteins that restore ER homeostasis, including components of the ER-associated degradation (ERAD) pathway. IRE1 $\alpha$ also degrades ribosomal mRNAs encoding secretory proteins in a process known as regulated IRE1-dependent decay (RIDD) and activates the c-Jun $\mathrm{N}$-terminal kinase (JNK), which in turn induces inflammation and apoptosis. ATF6 translocates to the Golgi once activated, where it is cleaved by site $1 / 2$ proteases (S1P and S2P), forming a transcription factor that translocates to the nucleus to activate genes encoding chaperones, ERAD components and XBP1.

grows the capacity of the ER (Calfon et al. 2002, Lee et al. 2003). IRE1 $\alpha$ can also selectively degrade the mRNA for secretory proteins in a process known as regulated IRE1dependent decay and it is possible that strong IRE1 activation contributes to the eventual reduction of

Published by Bioscientifica Ltd. 
preproinsulin biosynthesis in T2D (Hollien et al. 2009, Benhamron et al. 2014, Coelho \& Domingos 2014).

ATF6 translocates from the ER to the Golgi after disengagement from GRP78, and in the Golgi, it is cleaved by Golgi-resident enzymes resulting in the release of the ATF6 transcription factor, which drives expression of GRP78, other ER resident chaperones and XBP1 to help restore ER homeostasis (Haze et al. 1999, Yoshida et al. 2001). There are two isoforms of ATF6, with ATF6 $\alpha$ being the major driver of ER stress-induced gene expression but subjected to rapid degradation, whereas ATF6 $\beta$ may be a negative regulator of ATF6 $\alpha$ (Thuerauf et al. 2007).

\section{Disturbed $\beta$-cell ER homeostasis causes diabetes}

The most direct evidence that protein misfolding and ER stress in $\beta$-cells can cause diabetes comes from a syndrome called mutant INS-gene induced diabetes of youth (MIDY) involving misfolding mutations in the INS gene with 30 dominant mutations documented to date (Liu et al. 2015, Sun et al. 2015). The underlying cellular and molecular pathology has been most extensively explored in the Akita mouse model in which heterozygous mice carry a mutated Ins2 allele identical to a clinically reported missense mutation (Yoshioka et al. 1997). Despite carrying one WT copy of Ins 2 and two WT Ins1 alleles, diabetes develops early in life due to progressive $\beta$-cell apoptosis associated with proinsulin misfolding, $\beta$-cell ER stress and $\mathrm{CHOP}$ expression (Oyadomari et al. 2002).

UPR activation is often used as a measure of ER stress, and because the UPR can induce inflammation and apoptosis, there is a tendency to equate UPR activation with deleterious consequences. However, lessons from both human monogenic diabetes and genetic models in mice show that a fully functioning UPR is required to maintain normal homeostasis in $\beta$-cells.

Wolcott-Rallison syndrome is a rare autosomal recessive disease caused by EIF2AK3 (encodes PERK) mutations with multiorgan dysfunction, including a characteristic neonatal diabetes characterised by $\beta$-cell depletion (Julier \& Nicolino 2010, Collardeau-Frachon et al. 2014). Mice lacking PERK develop a similar phenotype, including early onset diabetes, showing defects in $\beta$-cell proliferation and differentiation and causing ER dilation, proinsulin accumulation, abrogation of insulin secretion and neonatal hyperglycaemia (Zhang et al. 2002, 2006). Interestingly, the depletion of PERK in adult mice did not substantially affect $\beta$-cell function or glycaemic control, suggesting PERK is most essential during $\beta$-cell differentiation (Zhang et al. 2002, 2006). Further studies, surprisingly, have indicated that the loss of PERK does not cause pathology as a result of uncontrolled protein biosynthesis due to the loss of the block in translation, but rather via impaired ER to Golgi trafficking and impaired removal and degradation of misfolded proteins from the ER (Gupta et al. 2010). Mice carrying an eIF $2 \alpha$ mutation, which prevents the PERK-mediated phosphorylation event that reduces secretory protein translation, show high rates of proinsulin synthesis that are not reduced by ER stress. Consequently, these mice develop diabetes and, in addition to increased proinsulin translation, show defective $\beta$-cell ER protein trafficking, increased ROS/RNS, reduced expression of $\beta$-cell-specific transcription factors and increased apoptosis (Back et al. 2009).

$\beta$-cell-specific deletion of Xbp1 results in ER distension, decreased formation of insulin granules, impaired proinsulin processing, reduced insulin secretion, increased serum proinsulin:insulin ratio and reduced $\beta$-cell proliferation, demonstrating the essential role of XBP1 in $\beta$-cell homeostasis (Lee et al. 2011). This study also showed that the absence of Xbp1 resulted in hyperactivation of Ire $1 \alpha$, which can have non-Xbp1-mediated signalling effects, suggestive of a direct feedback mechanism. Atf6 knockout mice develop higher ER stress and reduced glycaemic control on high fat diets or when carrying the Akita Ins2 allele, although interpretation of these findings are clouded by effects in other tissues including the liver (Usui et al. 2012). Nevertheless, in cultured murine insulinoma $\beta$-cells, silencing of Atf6 reduced Grp78 protein levels, activated c-Jun N-terminal kinase (Jnk) and increased apoptosis in the absence of stressors, suggesting that ATF6 is also involved in $\beta$-cell homeostasis (Teodoro et al. 2012).

The Wolfram syndrome 1 (WFS1) protein provides an important dynamic and UPR-independent link between ER stress and regulation of insulin secretion. Over 100 different mutations in WFS1 result in Wolfram syndrome, which is a monogenic diabetes characterised by juvenile onset and progressive $\beta$-cell depletion. An impaired ER stress-response phenotype has been shown in human WFS1 $\beta$-cells differentiated from patient-derived pluripotent stem cells that, on exposure to ER stress, show impaired insulin processing and GSIS (Shang et al. 2014). Another important consequence of ER stress is the depletion of $\mathrm{ER} \mathrm{Ca}^{2+}$, which results in increased protein misfolding and has been proposed as a UPR-independent trigger for the calpain-2-mediated apoptosis pathway in response to glucolipotoxicity and oxidative and ER stress (Hara et al. 2014). An ER membrane sarco(endo)plasmic

Published by Bioscientifica Ltd. 
reticulum ATPase (SERCA) is responsible for maintaining high concentrations of $\mathrm{Ca}^{2+}$ in the ER. Interactions between WFS1 and SERCA have been shown, with WFS1 appearing to be a negative inhibitor of SERCA by targeting it for proteosomal degradation (Zatyka et al. 2015). ER stress also appears to disrupt the WFS1-SERCA interaction,

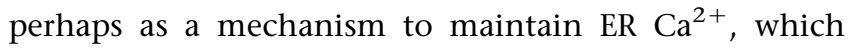
could further impact $\mathrm{Ca}^{2+}$-dependent insulin secretion (Zatyka et al. 2015). Taken together, these findings suggest that any form of $\beta$-cell ER stress is likely to impair both insulin biosynthesis (via misfolding and the UPR block of translation) and insulin granule release (via altered SERCA degradation).

\section{Pathological consequences of $\beta$-cell oxidative and ER stress}

We argue that experimentally it is very hard to distinguish effects of oxidative stress and ER stress in $\beta$-cells because they are intrinsically entwined. Consequently, experimental studies inducing either oxidative or ER stress need to include considerations of both forms of stress and their biochemical and cellular consequences. Aside from effects on the ER, high concentrations of ROS and RNS can promote NF- $\kappa \mathrm{B}$ activation, induce DNA damage and alter mitochondrial membrane potential, making cytochrome $c$ release and apoptosis more likely (Lowell \& Shulman 2005, Supale et al. 2012). While the adaptive UPR has evolved primarily to allow the cell to restore normal function in the secretory pathway and the evidence outlined above shows that UPR signalling is integral to $\beta$-cell homeostasis, there are multiple pathological consequences of the stress itself that, together with strong or prolonged UPR signalling, can explain much of $\beta$-cell dysfunction in T2D.

\section{Intrinsic ER functions}

Stress in the $\beta$-cell ER is likely to feature lower than optimal $\mathrm{Ca}^{2+}$ concentrations adversely affecting chaperone function, a higher than optimal oxidizing environment potentially affecting disulphide bond formation (and reduction of disulphide bonds as a necessary step in ERAD), progressive sequestration of chaperones to misfolded proteins and stress on the ERAD and ER to Golgi trafficking processes, which are heavily reliant on chaperones and movement of cargo by membrane-anchored proteins. The net effect of this disturbed environment for protein folding, processing and transport will be strain on the ability of the $\beta$-cell to manufacture, process and store sufficient insulin to cope with demand and to appropriately regulate insulin secretion.

While in acute ER stress the PERK/eIF2 $\alpha$-mediated translation block would help restore homeostasis, in the state of chronic ER stress characteristic of evolving T2D, this does not appear to occur, suggesting that there is adaptation in the nature of the UPR or responsiveness to UPR signals. We should stress that increased insulin secretion at this time could be achieved not only by increased secretion in individual cells but also by the increase of $\beta$-cell mass or recruitment of more $\beta$-cells into secretion in response to each glucose load. The adaptation in the UPR is, of course, necessary; otherwise, $\beta$-cell insulin secretion and glycemic control would be rapidly abolished under conditions of continuing stress. Most in vitro experiments are conducted with relatively short durations of experimental stress, typically using strong triggers to induce a rapid response vs the chronic lower level stress likely to be encountered by $\beta$-cells in T2D (measured in months or years rather than hours), and thus care should be taken in extrapolating from in vitro data. In prediabetes and the early phases of diabetes, insulin hypersecretion is evident with progressive serum hyperinsulinaemia and hyperproinsulinaemia. Similarly, mice fed high fat diets show serum hyperinsulinaemia and hyperproinsulinaemia, and their islets hypersecrete insulin on ex vivo glucose challenge (Hasnain et al. 2014). In chronic ER stress, quality control mechanisms that retain misfolded proteins in the ER are relaxed or overwhelmed, allowing misfolded proteins to move to the Golgi and be packaged for secretion (Chen et al. 2015). One sign of relaxed ER quality control is the accumulation of misfolded amyloid proteins in the extracellular space, and accumulation of $\beta$-amyloid in human pancreatic islets is a well-characterised feature of T2D that has been linked with oxidative stress, inflammatory signalling and apoptosis (Zraika et al. 2009, Masters et al. 2010, Jurgens et al. 2011, Meier et al. 2014). Relaxation or overwhelming quality control will not only allow secretion of protein products (albeit potentially inappropriately folded) but also reduce the burden on ERAD to dispose of misfolded proteins.

In direct contrast to the PERK-mediated translation block, the experimental overexpression of ATF4 and CHOP, which are both downstream of PERK, drives increased protein transcription, protein biosynthesis and oxidative stress, and it appears that ROS may be the major driver of apoptosis under these conditions (Han et al. 2013). Although proinsulin may be particularly susceptible to misfolding, insulin represents $<50 \%$ of the secretory pathway biosynthetic load of a $\beta$-cell and the

Published by Bioscientifica Ltd 
consequences of increased misfolding, and reduced biosynthesis of other secretory proteins, including accessory proteins critical to insulin processing, transport, packaging and secretion, also warrants consideration.

\section{Apoptosis}

ER stress-induced apoptosis has been the subject of a relatively intense focus due to the ability of UPR signalling to engage apoptosis, which is likely to have evolved as a mechanism for eliminating terminally stressed and virally infected cells. $\beta$-cell apoptosis ensues from strong prolonged triggers for ER stress in vitro including exposure to chemicals that directly cause protein misfolding such as tunicamycin (inhibitor of $\mathrm{N}$-glycosylation in the ER) and thapsigargin (disturbs SERCA-mediated $\mathrm{Ca}^{2+}$ retention in the ER) or environmental factors such as cytokines and glucolipotoxicity (Oyadomari et al. 2002, Contreras et al. 2003, Cardozo et al. 2005, Endo et al. 2006, Ito et al. 2006, Cunha et al. 2008, Papa 2012, Yang et al. 2013). There are several mechanisms by which UPR signalling that is above a threshold drives $\beta$-cell apoptosis with the most important being PERK/ATF4-mediated activation of CHOP and IRE1 $\alpha$ /TRAF2/ASK1-mediated activation of JNK (reviewed in Papa (2012)). While early evidence implicated caspase 12 as a critical effector of ER stress-induced apoptosis (Nakagawa et al. 2000, Oyadomari et al. 2002), CHOP induces the pro-apoptotic BCL2 family member BIM in $\beta$-cells (Puthalakath et al. 2007, Miani et al. 2013), and hyperactivation of JNK induces apoptosis in $\beta$-cells by inhibiting anti-apoptotic BCL2 family members (Urano et al. 2000). The deletion of CHOP reduces $\beta$-cell apoptosis in mouse models of T2D and MIDY, consistent with an important role (Oyadomari et al. 2002, Song et al. 2008). In contrast, in the non-obese diabetic model of autoimmune diabetes where ER stress has been shown to develop early in pathology prior to frank insulitis or the onset of diabetes (Tersey et al. 2012), CHOP deficiency did not affect the development of insulitis, diabetes or apoptosis but did delay the appearance of insulin autoantibodies (Satoh et al. 2011), suggesting either ER stress is not involved in triggering apoptosis or a CHOPindependent mechanism is involved. Activated PERK also inhibits the production of the anti-apoptotic protein, XIAP, and ATF4 increases XIAP degradation, potentially explaining the decreased threshold to apoptosis in ER-stressed cells (Hiramatsu et al. 2014).

ER stress can also induce autophagy, which in turn can lead to the induction of apoptosis, but autophagy is also an important mechanism for the removal of terminally misfolded proteins from the ER, and there are conflicting data regarding autophagy and ER stress-induced apoptosis (Wang et al. 2012, Lee 2014). $\beta$-cell-specific Atg7-null mice with impaired autophagy have reduced $\beta$-cell mass, mild ER stress, lower pancreatic insulin content and mild hyperglycaemia, and when crossed onto a leptin deficient background, they develop severe $\beta$-cell ER stress and diabetes (Quan et al. 2012), demonstrating a critical role for autophagy in maintaining $\beta$-cell ER homeostasis. While it is clear experimentally that oxidative and ER stress can induce apoptosis in $\beta$-cells and that this process may be integrally involved in misfolding-induced apoptosis in MIDY, the significance of $\beta$-cell apoptosis in T2D remains a subject of debate and is addressed further later.

\section{Inflammation}

Another important consequence of oxidative and ER stress with strong or prolonged UPR signalling is the generation of inflammatory signals, a topic that we have recently reviewed elsewhere (Hasnain et al. 2012). ROS and RNS can lead also to NF- $\kappa$ B activation in $\beta$-cells and to inflammasome activation thus driving $\beta$-cell interleukin 1 beta (IL1ß) secretion (Menu et al. 2012). A potential critical regulator of this process is the thioredoxin interacting protein (TXNIP), which binds thioredoxin, thereby inhibiting its oxidant scavenging and thiol-reducing capacity (Shalev 2014). Deficiency of TXNIP protects $\beta$-cells from stress, mitochondrial dysfunction and inflammation in diabetes (Chen et al. 2008a,b, 2010). However, TXNIP pathways are complex and there is emerging evidence that the UPR, via PERK and IRE1, regulates the expression of TXNIP, providing a direct molecular link between the regulation of ER stress and oxidative stress (Lerner et al. 2012, Oslowski et al. 2012). Providing another example of how cells respond to concomitant oxidative and ER stress, high cytosolic $\mathrm{Ca}^{2+}$ (due to ER leakage) and ROS can together induce NF- $\kappa \mathrm{B}$ activation in a classical UPRindependent manner (Pahl \& Baeuerle 1996). In an action distinct from its enzymatic activity, the IRE $1 \alpha$ cytoplasmic domain engages TNF-receptor activating factor 2 (TRAF2), which then binds NF- $\kappa$ B protein I $\kappa$ B kinase (IKK), leading to $\mathrm{I} \kappa \mathrm{B} \alpha$ degradation and activation of NF- $\kappa \mathrm{B}$ transcription factors (Kaneko et al. 2003). NF- $\mathrm{kB}$ is a master regulator of inflammatory signalling, and thus, ER stress can induce genes encoding cytokines and chemokines in $\beta$-cells. IRE1/TRAF2 engagement can also induce activation of AKT and JNK with subsequent activation of downstream inflammatory pathways. It has also been proposed that suppression of translation mediated by PERK/eIF2 $\alpha$ results

Published by Bioscientifica Ltd. 
in decreased translation of the inhibitory $\mathrm{I} \kappa \mathrm{B} \alpha$ protein, therefore leading to NF- $\mathrm{B}$ activation (Jiang et al. 2003, Deng et al. 2004). In response to ER stress caused by bacterial toxins, ATF6 also activates NF- $\kappa$ B via phosphorylation of AKT, independently of IRE1 $\alpha$ (Yamazaki et al. 2009). Leakage of GRP78 into the cytoplasm during ER stress and a direct interaction between GRP78 and the IKK complex has been proposed as an additional UPRindependent mechanism linking ER stress to immune activation (Shkoda et al. 2007).

In summary, there are multiple mechanisms that can lead oxidative and ER stress to inflammatory signalling and/or apoptosis in $\beta$-cells, which in turn will lead to the activation of local islet resident cells, including the macrophages that are intertwined with $\beta$-cells, dendritic cells, T cells, myofibroblasts and endothelial cells, as well as increased leukocyte recruitment from the blood (Toyama et al. 2003, Coppieters et al. 2012, Calderon et al. 2015). Next, we address the complex environmental exposures that lead to $\beta$-cell stress in T2D.

\section{Drivers of $\beta$-cell oxidative and ER stress in T2D}

Although the evidence provided above highlights the importance of the appropriate function of $\beta$-cell intrinsic homeostatic factors to maintain $\beta$-cell secretory function, much of the $\beta$-cell dysfunction in sporadic T2D is initiated by environmental stressors. It is important to note that $\beta$-cell dysfunction is not a universal response to these stressors, and some genetic associations with susceptibility have now been reported (Haupt et al. 2009). In susceptible individuals, the most important non- $\beta$-cell-intrinsic contributors to $\beta$-cell oxidative and ER stress in T2D include an increased demand for insulin biosynthesis in response to hyperglycaemia due to high nutrient intake, peripheral insulin resistance and increased hepatic gluconeogenesis; glucolipotoxicity due to increased circulating concentrations of glucose and non-esterified fatty acids (NEFAs); and exposure to inflammatory factors sourced from islet resident secretory cells, leukocytes and stromal cells (Back \& Kaufman 2012, Cnop et al. 2012, Papa 2012). We argue that these factors combine to stress the $\beta$-cell secretory pathway and are interconnected in their pathophysiology, and we will discuss each in more detail below.

\section{Increased insulin biosynthesis}

Increasing pressure on $\beta$-cells to synthesise and secrete more insulin is an inexorable consequence of the progression of diabetes as glycaemic control progressively wanes. As discussed above, the chronic ER stress that develops with prediabetes and early diabetes is associated with increasing serum insulin, which is typically accompanied by decreasing intracellular stores of insulin in $\beta$-cells (Hasnain et al. 2014). Under these conditions, the $\beta$-cells are manufacturing large quantities of insulin under suboptimal conditions within the ER and almost continuously secreting some insulin, although secretion still surges post-prandially. An important element of obesity and diabetes with relevance to $\beta$-cell ER health is the diminishing phases of 'rest' for the $\beta$-cell, which are likely to be important not just to replenish insulin granules for secretion but also to undertake ER housekeeping (removal of misfolded proteins, replenishment of chaperones and processing enzymes like protein disulphide isomerases and re-establishment of an appropriate $\mathrm{Ca}^{2+}$ concentration and oxidising environment). Evidence from partial pancreatectomies suggest that there are more islets than are required to secrete sufficient insulin for glycaemic control, and the net effect of over-sufficiency is likely to be less stress on individual $\beta$-cells. Although the degree of $\beta$-cell depletion in T2D is debated, loss of $\beta$-cells as diabetes progresses will place more biosynthetic strain on the remaining individual $\beta$-cells.

\section{Glucolipotoxicity}

The progressive hyperglycaemia experienced in T2D itself directly causes $\beta$-cell stress, which impairs $\beta$-cell function and survival due to glucotoxicity. When excessive glucose is available to the $\beta$-cell, unwarranted ROS and RNS are generated by several pathways, including mitochondrial production of $\mathrm{O}_{2}^{-}$and induction of the NOS2 gene encoding iNOS catalysing production of $\mathrm{NO}$, which also mediates $\beta$-cell responses to cytokines and NEFAs and can instigate apoptosis (Lenzen 2008, Bensellam et al. 2012). Elevated ROS perturbs insulin synthesis and secretion by decreasing the expression and activity of key transcription factors such as PDX1 and MAFA, which are involved in regulating insulin transcription, although as discussed earlier, glucose itself normally drives increased insulin transcription (Andrali et al. 2008, Rutter et al. 2015). Under high glucose conditions, it is possible that increased proinsulin biosynthesis may overwhelm the ER protein folding capacity leading to UPR activation. Long exposures $(24 \mathrm{~h})$ of $\beta$-cells to high glucose cause hyperactivation of IRE1 $\alpha$ and splicing of XBP1, whereas acute exposure (1-3 h) to high glucose activates IRE1 $\alpha$ without XBP1 splicing (Lipson et al. 2006). Rat islets exposed to high glucose ex vivo also show UPR activation (Elouil et al. 2007).

Published by Bioscientifica Ltd. 
Alongside hyperglycaemia, hyperlipidaemia is a characteristic feature of obesity and T2D, and chronically elevated circulating levels of NEFAs are putative mediators of progressive $\beta$-cell dysfunction and death in T2D. Consequently, the adverse consequences of glucose and lipids are often grouped together as glucolipotoxicity. In a clinical experiment using lipid infusions to raise circulating NEFA levels by twofold above the basal level, obese nondiabetic individuals showed a significant reduction in GSIS, whereas this did not deteriorate further in diabetics (Carpentier et al. 2000). The NEFA palmitate has been widely used experimentally to induce both oxidative and ER stress in murine and human $\beta$-cells and islets (Cunha et al. 2008, Cnop et al. 2010, Igoillo-Esteve et al. 2010, Hasnain et al. 2014). High NEFA exposure results in the production of $\mathrm{O}_{2}^{-}$and $\mathrm{ONOO}^{-}$by $\beta$-cell mitochondria and drives expression of NOS2 leading to the production of NO, thereby inducing oxidative and ER stress. Palmitate and the unsaturated fatty acid oleate also affect $\mathrm{Ca}^{2+}$ handling in the ER leading to protein misfolding and ER stress apparently independently of oxidative stress (Cnop et al. 2010), although oleate causes much milder ER stress than palmitate (Cunha et al. 2008). Other reports indicate that palmitate rapidly increases the saturated lipid content of the ER, which leads to compromised ER morphology and integrity resulting in ER stress, and interestingly, NEFA exposure causes ER stress in yeast demonstrating a fundamental mechanism not restricted to mammalian cells (Borradaile et al. 2006, Pineau \& Ferreira 2010, Boslem et al. 2011). Desaturation of palmitate with stearoyl coenzyme A desaturase 1 (SCD1) reduces palmitateinduced cell death, whereas deficiency increases apoptosis (Busch et al. 2005, Thorn et al. 2010, Green \& Olson 2011). Consistent with these in vitro observations, SCD1 levels are markedly reduced in Zucker diabetic fatty rats (Green \& Olson 2011), and deficiency of SCD1 in leptin-deficient obese mice worsens diabetes (Flowers et al. 2007). In summary, both high glucose and high NEFAs induce oxidative stress in $\beta$-cells, which in turn can induce protein misfolding and ER stress, with NEFAs also directly causing ER stress by oxidative stress-independent mechanisms.

Much clinical data exists supporting the glucolipotoxicity concept. As outlined above, acute experiments with glucose and/or lipid loading decrease $\beta$-cell function in man. Conversely, acute reduction of glucolipotoxity with interventions such as energy restriction, bariatric surgery or early intensive insulin treatment induces significant restoration of $\beta$-cell function.

\section{Cytokine-induced stress}

Low level chronic inflammation within islets in the absence of conspicuous inflammatory infiltrates are characteristic of animal models and human T2D and is increasingly being recognized as an important contributor to $\beta$-cell dysfunction (Donath et al. 2009, 2013, Donath 2013, Imai et al. 2013). Unlike T1D, there is little evidence of significantly increased infiltration of T cells or NK cells into T2D islets and, therefore, activation of resident leukocytes, including macrophages and dendritic cells, is probably most important. Increased fibrosis is also a feature of T2D, and fibroblasts can be prodigious producers of innate cytokines (Powell et al. 1999, Hayden et al. 2008). Most of the focus on cytokines in T2D has been on a restricted set of cytokines implicated in diabetes pathology some time ago, namely, IL1 $\beta$, IL6, TNF $\alpha$ and IFN $\gamma$. There are two main areas of focus on the linkage between ER stress and inflammation: how ER stress induces inflammatory signalling by $\beta$-cells and how local inflammatory factors induce $\beta$-cell ER stress and ER-stress-induced apoptosis, although again the focus has usually been restricted to IL1 $\beta$, TNF $\alpha$ and IFN $\gamma$ (Akerfeldt et al. 2008, Gurzov et al. 2009, Allagnat et al. 2010, Chan et al. 2011, 2012, Kacheva et al. 2011). Much of the ER stress induced by cytokines is likely attributable to the induction of oxidative stress via a variety of downstream pathways, the most notable being the induction of NOS2 and production of NO (Arnush et al. 1998, Chan et al. 2011, Ellingsgaard et al. 2011, Gurgul-Convey et al. 2011, Kacheva et al. 2011, Broniowska et al. 2013, 2014). ROS such as $\mathrm{H}_{2} \mathrm{O}_{2}$ can impair the action of the protein tyrosine phosphatases that are important elements of dampening signal pathways, including cytokine pathways (Merry et al. 2014, Gurzov et al. 2015). Therefore, oxidative stress can inherently amplify cytokine signalling in a forwardfeeding loop, perhaps explaining the development of stress in the presence of relatively low cytokine concentrations. However, there is experimental evidence suggesting that pathways unrelated to oxidative stress also mediate cytokine-induced ER stress in $\beta$-cells, although it must be said that this area is plagued by methodological difficulties and some of these results are open to alternative interpretations (Cardozo et al. 2005, Chen et al. 2005). Cytokines also have potentially deleterious effects on $\beta$-cells due to pathways unrelated to oxidative and ER stress, which need to be considered in the totality of their effects.

Recently, we undertook a screen using individual and combinations of 23 different cytokines for their ability to

Published by Bioscientifica Ltd 
induce ER stress measured by a reporter gene for IRE1 $\alpha$ activation/XBP1 splicing in murine MIN6N8 insulinoma cells. While this screen confirmed that cytokines like IL1 $\beta$ and IFN $\gamma$ initiate ER stress, we found there were other cytokines, not previously implicated in $\beta$-cell dysfunction, that were much more potent inducers of $\beta$-cell ER stress, most notably IL17, IL23, IL24 and IL33 (Hasnain et al. 2014). In addition to activating IRE $1 \alpha$, we showed that these cytokines also activated PERK and ATF6, indicating all three major arms of the UPR were engaged. These cytokines also drove ER stress in murine and human islets cultured ex vivo. In our hands, using combinations of chemical inhibitors of ROS and RNS, we were able to nearly completely prevent ER stress induced by each of the major stress-inducing cytokines, confirming oxidative stress as the major driver of $\beta$-cell cytokine-induced ER stress (Hasnain et al. 2014). Of course, these cytokines would need to be elevated in the islet to impact $\beta$-cells and we found their mRNA to be increased in islets from obese mice fed a high fat diet or with leptin receptor deficiency. Furthermore, our analysis of the largest published transcriptome analysis comparing T2D and healthy islets (Mahdi et al. 2012) found that, among the 100 most upregulated genes in T2D, the differentially expressed cytokine and cytokine receptor genes were (in order of upregulation) those encoding the IL33 receptor, IL33, IL24, the IL1 $\beta$ decoy and cell surface receptors and the IL22 receptor (Hasnain et al. 2014). We then treated high fat diet-fed obese mice for 2 weeks with neutralizing antibodies against IL23 and IL24 and demonstrated partial restoration of glycaemic control, similar to that previously demonstrated with IL1 $\beta$ neutralizing antibodies, accompanied by reduced serum hyperinsulinaemia and hyperproinsulinaemia and reduced pancreatic ER stress (Hasnain et al. 2014). Although effects of neutralising these cytokines on non-pancreatic tissues cannot be excluded from contributing to the restoration of glycemic control, these findings suggest that a more thorough examination of the totality of inflammatory drivers of $\beta$-cell function in T2D is required. Potential therapeutic opportunities related to cytokine-mediated ER stress are discussed in the last section of the review.

\section{$\beta$-cell intrinsic and local environmental factors that protect $\beta$-cells from oxidative and ER stress}

Although $\beta$-cells have been regarded as being particularly susceptible to oxidative and ER stress (Lenzen 2008), consideration should be given to the context in which these experiments have been conducted, which could possibly overestimate $\beta$-cell susceptibility. Most experiments (including ours described above) have been conducted with cultured, typically transformed $\beta$-cell lines lacking potentially vital local islet secreted factors and cellular interactions provided by stromal cells and leukocytes within islets. Cultured islets may more faithfully reproduce in vivo conditions, but these multicellular clusters start to degenerate physically and biochemically when isolated and cultured ex vivo. For example, little is known about the ramifications for islet leukocyte survival and activation in the context of islet cultures, and critical cell-cell interactions are likely to be substantially disturbed by isolation and culture (Peiris et al. 2014). Although cytokines are likely to contribute to progressive loss of $\beta$-cell function, some cytokines may have advantageous effects and could be involved in $\beta$-cell homeostasis, particularly early in the disease process. For example, although much attention has been given to the deleterious effects of IL1 $\beta$, low concentrations of IL1 $\beta$ promote $\beta$-cell proliferation and therefore may be critical to expanding $\beta$-cell mass in response to the requirement for increased insulin production (Maedler et al. 2006). Recently, IL6 has been shown to stimulate GLP1 secretion by islet $\alpha$-cells, thereby increasing $\beta$-cell insulin secretion (Ellingsgaard et al. 2011). Our recent discovery that IL22 protects $\beta$-cells from oxidative and ER stress is described below, and the favourable therapeutic effects of IL22 are depicted in Fig. 4.

In our studies described above that aimed to identify ER stress-inducing cytokines, when stress inducing-cytokines were combined, we found amplification of ER stress. This additivity is predictable given that we showed that these cytokines used differing downstream pathways to induce oxidative stress. However, more importantly, we discovered that IL10 and IL22 inhibited the development of ER stress driven by all of the stress-inducing cytokines, with IL22 acting more potently than IL10 (Hasnain et al. 2014). IL10 and IL22 are part of the same subfamily of cytokines and share a common protein, IL10R2, in their heterodimeric cell surface receptors (Ouyang et al. 2011). The IL10 receptor is ubiquitously expressed, and IL10 is a thoroughly studied immunoregulatory cytokine that is generally involved in maintaining tissue homeostasis and suppressing inflammatory responses, for example, in recovery postinfection. IL22 is a cytokine involved in homeostasis, microbial defence, inflammation and postinfection repair in the skin and mucosal tissues (Sabat et al. 2013). IL22 signals via the IL22R1 receptor, which in humans and mice is expressed more highly in the pancreas

Published by Bioscientifica Ltd. 


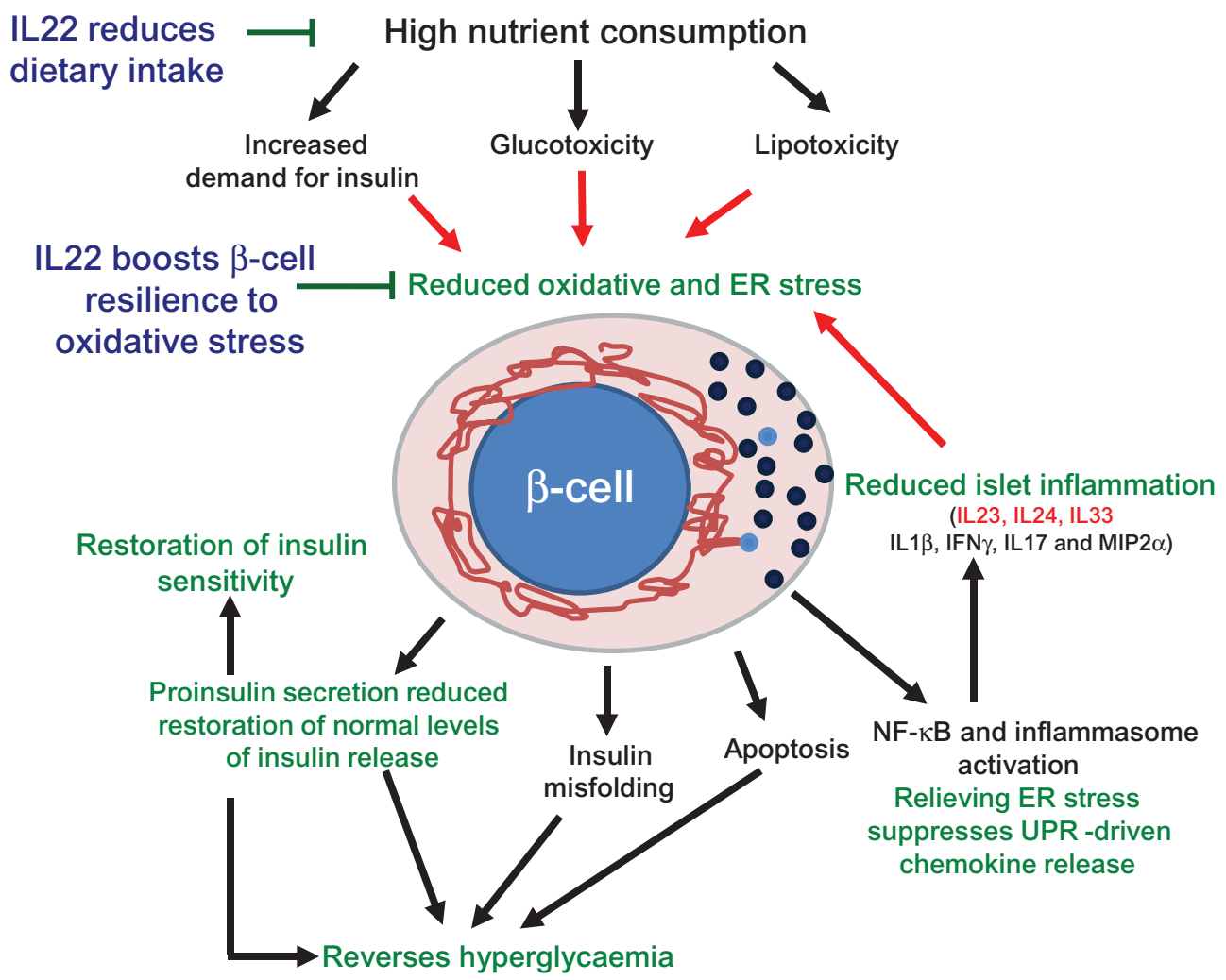

\section{Figure 4}

Schematic representation of how IL22 treatment breaks the cycle of pancreatic islet ER stress and inflammation and restores glucose homeostasis in diabetes. IL22 acts to suppress $\beta$-cell oxidative stress via IL22 receptor-mediated activation of STAT1 and STAT3, thereby regulating key genes encoding proteins that degrade reactive oxygen species (ROS) and reactive nitrogen species (RNS) and suppressing genes encoding proteins that generate ROS and RNS. Resolution of stress improves insulin biosynthesis, leading to the release of an appropriate amount of insulin, suppression of proinsulin release and reduction of chemokine production.

than any other tissues. In the pancreas IL-22R1 is expressed in the exocrine secretory cells, but the highest levels are in the islet secretory $\alpha$-, $\beta$ - and $\delta$-cells (Shioya et al. 2008). It is important to point out that, unlike most cytokines, including IL10, IL22 does not act on leukocytes as they lack the receptor. Despite the high receptor expression in $\alpha$ - and $\beta$-cells, functional studies of IL22 in the pancreas prior to our study were restricted to acute pancreatitis in the exocrine pancreas, demonstrating that exogenous IL22 suppresses inflammation (Feng et al. 2012, Xue et al. 2012). We have discovered that IL22 is a previously unrecognized potent endogenous paracrine regulator of $\beta$-cell function. IL22 suppresses $\beta$-cell production of ROS and NO initiated by cytokines, palmitate and even exogenous $\mathrm{H}_{2} \mathrm{O}_{2}$ and consequently blocks ER stress. Similarly, we also showed that IL22 has a similar protective effect in mouse and human islets and, by
Reduced chemokine release leads to less leukocyte recruitment, activation and cytokine secretion. Diminished production of stressor cytokines in the islet microenvironment further diminishes ER stress as well as oxidative stress, restoring high quality insulin release, which resolves hyperglycaemia and hyperinsulinaemia. Subsequently, peripheral insulin sensitivity is restored further depressing the demand for insulin, and glucose homeostasis is re-established. In addition, IL22 therapy reduces food intake, potentially via improved insulin-mediated hypothalamic control of appetite, which is also likely to contribute to the beneficial effects.

blocking IL22 signalling with antibodies against IL22R1, we have demonstrated that endogenous IL22 suppresses oxidative stress and ER stress in normal murine and human islets (Hasnain et al. 2014). Thus, IL22 is an important modulator of healthy islet function. These data challenge the dogma that $\beta$-cells are highly susceptible to oxidative and ER stress because, given the physiological microenvironmental support by IL22, $\beta$-cells can be highly resistant to oxidative stress.

IL22 acts on $\beta$-cells via IL22R1 and downstream via both STAT1 and STAT3 transcription factors. In MIN6N8 cells, IL22 downregulates three oxidative stress-inducing genes: Nos2 (discussed above), Hsp90ab1 (involved in $\mathrm{ONOO}^{-}$production) and Fth1 (a carrier of $\mathrm{Fe}^{3+}$ ). Concomitantly, IL22 upregulates the antioxidant genes Gpx5 (deactivates $\mathrm{H}_{2} \mathrm{O}_{2}$ ), $\mathrm{Prd} \times 5$ (deactivates $\mathrm{ONOO}^{-}$and $\mathrm{H}_{2} \mathrm{O}_{2}$ ), Sod2 (deactivates $\mathrm{O}_{2}^{-}$) and $\mathrm{Cyba}$ (enhances

Published by Bioscientifica Ltd 
glutathione peroxidases and peroxiredoxins) (Hasnain et al. 2014). IL22 alters these genes independently of oxidative stress and can therefore protect cells from subsequent stressors, distinguishing IL22 from the Nrf2 transcription factor that is induced by oxidative stress (Uruno et al. 2015). Culture of islets from mice with highfat diet (HFD)-induced obesity with IL22 reduced ER stress, increased Sod2 and decreased Nos2, consistent with the effect on MIN6N8 cells. Islets from obese mice showed increased GSIS that returned to levels seen in non-obese islets when cultured in IL22 (Hasnain et al. 2014).

Treatment of obese mice with IL22 decreased islet ER stress, increased islet expression of Sod2 and suppressed Nos2, consistent with its effects on islets in vitro. Ex vivo cultured islets from IL22-treated obese mice had normalised insulin secretion, including reversal of the inappropriate secretion of proinsulin, paralleled by an almost complete reversal of serum hyperproinsulinaemia. Because increasing serum proinsulin correlates with increased insulin resistance and poor glycaemic control in obese mice and human diabetes, we assessed the functional quality of insulin by assessing glucose uptake in adipocytes. Stimulation of glucose uptake by insulin secreted by islets from obese mice was reduced by over two-thirds and returned close to that seen in islets from lean mice after in vivo IL22 therapy (Hasnain et al. 2014).

The observations with IL22 suggests that the sensitivity of $\beta$-cells to ER stress is dependent on local environmental support and opens many questions about how this might be utilised to restore $\beta$-cell secretory function in T2D. However, there is much to learn about the sources of IL22 within islets and how production is regulated, as this may be a key to appropriate therapy. Although less potent, the role of IL10 should not be overlooked, and decreased IL10 production by macrophages within the islet could conceivably be involved in $\beta$-cell dysfunction in T2D. The beneficial effects of IL22 in murine models of diabetes has been replicated in another recent study with very similar findings including the resolution of glycaemic control accompanied by reduced fasting and fed serum insulin concentrations (Wang et al. 2014). However, these authors propose a different mechanism of action of IL22 based chiefly around improvements in insulin resistance. Although we describe improvements in insulin sensitivity, we also demonstrate complete restoration of glycaemic control prior to any improvement in insulin sensitivity (Hasnain et al. 2014). Another study reports that IL22 can drive $\beta$-cell proliferation (Hill et al. 2013), but our unpublished data do not support this finding. Although our experiments suggest that the effects on $\beta$-cells could explain the major beneficial effects of IL22, we cannot exclude direct contributing effects outside the pancreas.

\section{Relative contributions of a dysfunctional secretory pathway vs $\beta$-cell depletion in T2D}

There is considerable debate about the relative contributions of the inability of individual $\beta$-cells to secrete sufficient insulin vs a progressive depletion of $\beta$-cells in T2D. While we have already detailed multiple pathways from oxidative and ER stress to apoptosis, there are somewhat divergent data about the extent of $\beta$-cell depletion in the human disease (Butler et al. 2003, Rahier et al. 2008), and we argue that dysfunctional insulin biosynthesis is the primary underlying feature of the disease. Evidence suggesting that $\beta$-cell depletion is not the primary problem in T2D include, as discussed earlier, the early phase of disease is characterised by insulin hypersecretion and inappropriate secretion of proinsulin; even the studies showing the highest amount of $\beta$-cell depletion are only $\sim 60 \%$ reduction and surgical removal of half the pancreas has a modest effect on glycaemic control (Menge et al. 2009); and bariatric surgery (Saliba et al. 2009), intense calorie restriction (Lim et al. 2011, Jackness et al. 2013) and administration of GLP1R agonists (Samson \& Garber 2013) restore glycaemic control and $\beta$-cell function. These data are relevant to the choice of therapeutic approaches and highlight that the $\beta$-cell dysfunction is likely to be reversible in many patients with T2D.

Our observations in obese mice treated with IL22 suggest that the poor quality of insulin secreted by the stressed $\beta$-cell is a major driver of hyperglycaemia. Our experiments with glucose uptake stimulated with the insulin secreted by cultured islets from obese mice suggest that much of the insulin is ineffective (Hasnain et al. 2014). We propose that under conditions of chronic ER stress, ER quality control mechanisms are relaxed or overwhelmed and, consequently, misfolded proinsulin is released from the ER. Subsequently, much of this misfolded proinsulin is not recognised and processed by convertases into insulin, explaining the accumulation of proinsulin in stressed $\beta$-cells and the progressively increased secretion of proinsulin that mirrors the progression of diabetes. We further hypothesise that the secreted misfolded insulin and proinsulin is less efficacious at stimulating insulin receptor signalling, thus explaining its lower efficacy, which in turn exacerbates insulin

Published by Bioscientifica Ltd. 
resistance. Clearance of the misfolded insulin and proinsulin may also be reduced as this is a receptormediated process, further explaining the characteristic hyperinsulinaemia and hyperproinsulinaemia in the early phases of diabetes. Under this hypothesis, therapies that can rapidly rectify oxidative and ER stress in $\beta$-cells would rapidly restore glycaemic control without the requirement for greater biosynthesis and secretion of insulin, which is precisely what we observed when islets from obese mice were treated with IL22 in vitro or when obese mice were treated with IL22, with glycaemic control being achieved with lower insulin secretion under fasting and following glucose challenge, even in the face of persisting insulin resistance (Hasnain et al. 2014). When high fat diet-fed or leptin receptor-deficient mice were treated with IL22, random fed blood glucose concentrations began to decrease within several days, consistent with a rapid reversal of $\beta$-cell dysfunction (Hasnain et al. 2014, Wang et al. 2014).

\section{Oxidative and ER stress is reversible and presents therapeutic opportunities in T2D}

Finally, we will address the therapeutic opportunities in T2D presented by $\beta$-cell dysfunction related to oxidative and ER stress beginning with a reflection on what effects current successful therapies have on the dysfunctional secretory pathway in the $\beta$-cell. Drugs that drive more insulin secretion, like the sulphonylureas, are likely to place more pressure on the secretory pathway in individual $\beta$-cells, and, consistent with this argument, this class of drug, although initially effective, is now considered to hasten the loss of $\beta$-cell function. In contrast, although GLP1 receptor agonists also promote insulin secretion, they do this in a glucose-dependent manner and may also directly protect $\beta$-cells from ER stress and promote proliferation (Yusta et al. 2006, Tsunekawa et al. 2007, Kim et al. 2012, Tortosa \& Dotta 2013). However, other data indicate that GLP1 receptor agonists also promote proinsulin secretion (Hasnain et al. 2014) and this may have longer-term deleterious consequences. Other drugs that decrease gluconeogenesis, such as metformin, increase glucose excretion, such as the SGLT2 inhibitors, or reduce peripheral insulin resistance, such as in thiazolidinediones, or the provision of exogenous insulin, should reduce the need for insulin biosynthesis and therefore indirectly relieve pressure on the $\beta$-cell secretory pathway, which is supported by evidence from clinical studies.

We finish by proposing potential approaches to more directly deal with $\beta$-cell dysfunction. However, it should be noted that many of these approaches could also affect the multiple organs involved in this disease, complicating the interpretation of experimental therapeutics. Additionally, while the focus of this review has been on $\beta$-cells, oxidative and ER stress also occurs in other islet secretory cells sharing the same microenvironment, most notably $\alpha$-cells, and their consequent dysfunction could contribute to diabetes pathophysiology and be the target of successful therapies (Walker et al. 2011, Akiyama et al. 2013, Marroqui et al. 2015). For example, in our studies of high fat diet-induced diabetes in mice, we observed substantial ER stress in $\alpha$-cells that was corrected by IL22 therapy (Hasnain et al. 2014). Although $\alpha$-cells appear more resistant to ER stress-induced apoptosis (Marroqui et al. 2015), ER stress could result in inappropriate secretion of glucagon, which drives hepatic gluconeogenesis. There is also evidence that chemokines released by $\alpha$-cells can initiate macrophage infiltration, activation and cytokine release in the diabetic islet (Ehses et al. 2007).

\section{Suppression of oxidative stress}

We have argued that oxidative stress is a central driving feature of $\beta$-cell dysfunction, including ER stress, which raises the question as to why antioxidant therapies, many of which have been trialled, often to target complications of diabetes, have not been more successful clinically. Our proposition is that the antioxidant drugs used to date are highly unlikely to be able to combat the high levels of $\beta$-cell oxidative stress driven continuously by $\beta$-cell intrinsic and local environmental factors. One possible approach is to target NADPH oxidases with proof or principle preclinical studies suggesting that the targeting of NOX2 or NOX4 could improve $\beta$-cell function (Li et al. 2012, Anvari et al. 2015). Our observations that IL22 drives a strong intrinsic antioxidant program in $\beta$-cells that decreases production and increases degradation of ROS and RNS open a new pathway to promoting $\beta$-cell resilience to oxidative stress caused by lipids, cytokines and protein misfolding. In humans, the IL22 receptor is most highly expressed in the pancreatic islets but also has a relatively high expression in epidermal and mucosal epithelia and, to a lesser extent, in hepatocytes. There is a possibility that there will be deleterious 'off-target' effects, potentially including proliferation, in tissues such as the skin and gut mucosa where there is high IL22 receptor expression (Cobleigh \& Robek 2013, Kumar et al. 2013, Rutz et al. 2013, Sabat et al. 2013). Consequently, approaches that drive local production of IL22 in the

Published by Bioscientifica Ltd 
islets could be the key to safe therapy capitalising on the potent effect of this cytokine on $\beta$-cell stress.

\section{Suppression of ER stress and UPR activation}

Apart from reducing oxidative stress, there are other approaches that could potentially reduce either the ER stress itself or manipulate the UPR, which is responsible for driving ER stress-induced inflammatory signalling and apoptosis. One approach to reducing ER stress is the use of pharmacologically delivered chemical chaperone-like molecules, such as 4-phenylbutyric acid and tauroursodeoxycholic acid (TUDCA), to promote correct protein folding (Engin \& Hotamisligil 2010). These chaperones have been used with some success in some murine models of diabetes (Ozcan et al. 2006, Luo et al. 2010, Xu et al. 2010, Engin et al. 2013, Cadavez et al. 2014), and TUDCA has advanced to clinical trials in obesity in which it had a modest effect on insulin sensitivity (Kars et al. 2010). This approach is probably awaiting a new class of more effective chemical chaperones with a differing side effect profile. As discussed earlier, the UPR is integral to maintaining $\beta$-cell homeostasis, and therefore the use of drugs that manipulate the UPR is potentially fraught. Additionally, this approach may also inhibit 'beneficial' UPR in other tissues. Although inhibitors of PERK and IRE1 $\alpha$ are available and have been used in vitro (Cross et al. 2012, Harding et al. 2012), there are no reports of successful resolution of $\beta$-cell dysfunction in diabetes in vivo with these drugs. Downstream targets of the UPR, particularly in the apoptosis pathway, provide alternative approaches with a lower risk of the exacerbation of ER stress (McKimpson et al. 2013). New drugs with specific downstream targets are becoming available, such as Sephin1, which targets the regulatory subunit of the stress-induced eIF $2 \alpha$ phosphatase and provides protection from misfolding stress in several murine genetic models of folding defects (Das et al. 2015).

\section{Suppression of islet inflammation}

We have described inflammatory cytokines produced within the islet as substantial contributors to $\beta$-cell oxidative and ER stress, making the individual cytokines and the cells that produce them potential therapeutic targets. Proof of this principle is quite well established in animal models, particularly for IL1 $\beta$, and we described above the identification of multiple other cytokines that should be considered as potential targets for T2D therapy. However, the degree of importance of cytokines for pancreatic islet dysfunction is less well established in human T2D. IL1 $\beta$ antagonists have been trialled in T2D with some efficacy, but overall with mixed results, suggesting that more appropriate patient stratification may be required (Cavelti-Weder et al. 2011, 2012, Rissanen et al. 2012, Boni-Schnetzler \& Donath 2013, Donath 2013, Sloan-Lancaster et al. 2013). Furthermore, the observation that multiple cytokines contribute to $\beta$-cell stress provides a possible explanation for the limited efficacy of IL1 $\beta$ antagonists in clinical trials and suggests that targeting several cytokines concomitantly may provide broader protection, although this is also more likely to increase adverse effects related to broad immunosuppression. The activation of cytokine-producing cells within the islets is likely to involve chemokine and other signals from stressed $\beta$-cells as well as systemic factors, such as the leakage of microbial products from the intestine. Gaining a deeper understanding of the immunopathology should open new opportunities to target the activation of and cytokine release by islet leukocytes and stromal cells.

In summary, in this review we have argued that oxidative stress and ER stress are entwined phenomena that are centrally placed in the progressive $\beta$-cell secretory pathway dysfunction characteristic of T2D. Although stress is driven by a complex array of environmental factors, it is reversible and open to the development of new therapeutic approaches that could be designed around natural programs driving antioxidant function in the $\beta$-cell. Importantly, such approaches are predicted to complement existing therapeutic strategies.

\section{Declaration of interest}

S Z Hasnain, J B Prins and M A McGuckin are inventors on a patent related to some of the findings discussed in this manuscript.

\section{Funding}

This work was supported by the National Health and Medical Research Council Project Grant 1081473. S Z Hasnain is supported by a University of Queensland Postdoctoral Research Fellowship and M A McGuckin is supported by a National Health and Medical Research Council Principal Research Fellowship 1059726.

\section{References}

Akerfeldt MC, Howes J, Chan JY, Stevens VA, Boubenna N, McGuire HM, King C, Biden TJ \& Laybutt DR 2008 Cytokine-induced $\beta$-cell death is independent of endoplasmic reticulum stress signaling. Diabetes $\mathbf{5 7}$ 3034-3044. (doi:10.2337/db07-1802)

Akiyama M, Liew CW, Lu S, Hu J, Martinez R, Hambro B, Kennedy RT \& Kulkarni RN 2013 X-box binding protein 1 is essential for insulin regulation of pancreatic $\alpha$ cell function. Diabetes 62 2439-2449. (doi:10.2337/db12-1747) http://jme.endocrinology-journals.org DOI: 10.1530/JME-15-0232
() 2016 Society for Endocrinology Printed in Great Britain 
Allagnat F, Christulia F, Ortis F, Pirot P, Lortz S, Lenzen S, Eizirik DL \& Cardozo AK 2010 Sustained production of spliced X-box binding protein 1 (XBP1) induces pancreatic $\beta$ cell dysfunction and apoptosis Diabetologia 53 1120-1130. (doi:10.1007/s00125-010-1699-7)

Andrali SS, Sampley ML, Vanderford NL \& Ozcan S 2008 Glucose regulation of insulin gene expression in pancreatic $\beta$-cells. Biochemical Journal 415 1-10. (doi:10.1042/BJ20081029)

Anvari E, Wikstrom P, Walum E \& Welsh N 2015 The novel NADPH oxidase 4 inhibitor GLX351322 counteracts glucose intolerance in high-fat diet-treated C57BL/6 mice. Free Radical Research 49 1308-1318. (doi:10.3109/10715762.2015.1067697)

Arcidiacono B, Iiritano S, Chiefari E, Brunetti FS, Gu G, Foti DP \& Brunetti A 2014 Cooperation between HMGA1, PDX-1, and MafA is essential for glucose-induced insulin transcription in pancreatic $\beta$ cells. Frontiers in Endocrinology 5 237. (doi:10.3389/fendo.2014.00237)

Arnush M, Heitmeier MR, Scarim AL, Marino MH, Manning PT \& Corbett JA 1998 IL-1 produced and released endogenously within human islets inhibits $\beta$ cell function. Journal of Clinical Investigation $\mathbf{1 0 2}$ 516-526. (doi:10.1172/JCI844)

Ashcroft FM \& Rorsman P 2012 Diabetes mellitus and the $\beta$ cell: the last ten years. Cell 148 1160-1171. (doi:10.1016/j.cell.2012.02.010)

Back SH \& Kaufman RJ 2012 Endoplasmic reticulum stress and type 2 diabetes. Annual Review of Biochemistry 81 767-793. (doi:10.1146/ annurev-biochem-072909-095555)

Back SH, Scheuner D, Han J, Song B, Ribick M, Wang J, Gildersleeve RD, Pennathur S \& Kaufman RJ 2009 Translation attenuation through eIF2 $\alpha$ phosphorylation prevents oxidative stress and maintains the differentiated state in $\beta$ cells. Cell Metabolism 10 13-26. (doi:10.1016/j.cmet. 2009.06.002)

Benhamron S, Hadar R, Iwawaky T, So JS, Lee AH \& Tirosh B 2014 Regulated IRE1-dependent decay participates in curtailing immunoglobulin secretion from plasma cells. European Journal of Immunology 44 867-876. (doi:10.1002/eji.201343953)

Bensellam M, Laybutt DR \& Jonas JC 2012 The molecular mechanisms of pancreatic $\beta$-cell glucotoxicity: recent findings and future research directions. Molecular and Cellular Endocrinology 364 1-27. (doi:10.1016/ j.mce.2012.08.003)

Bommiasamy H, Back SH, Fagone P, Lee K, Meshinchi S, Vink E, Sriburi R, Frank M, Jackowski S, Kaufman RJ et al. 2009 ATF6 $\alpha$ induces XBP1independent expansion of the endoplasmic reticulum. Journal of Cell Science 122 1626-1636. (doi:10.1242/jcs.045625)

Boni-Schnetzler M \& Donath MY 2013 How biologics targeting the IL-1 system are being considered for the treatment of type 2 diabetes. British Journal of Clinical Pharmacology 76 263-268. (doi:10.1111/j.1365-2125. 2012.04297.x)

Borradaile NM, Han X, Harp JD, Gale SE, Ory DS \& Schaffer JE 2006 Disruption of endoplasmic reticulum structure and integrity in lipotoxic cell death. Journal of Lipid Research 47 2726-2737. (doi:10.1194/jlr.M600299-JLR200)

Boslem E, MacIntosh G, Preston AM, Bartley C, Busch AK, Fuller M, Laybutt DR, Meikle PJ \& Biden TJ 2011 A lipidomic screen of palmitate-treated MIN6 $\beta$-cells links sphingolipid metabolites with endoplasmic reticulum (ER) stress and impaired protein trafficking. Biochemical Journal $\mathbf{4 3 5}$ 267-276. (doi:10.1042/BJ20101867)

Boucher J, Kleinridders A \& Kahn CR 2014 Insulin receptor signaling in normal and insulin-resistant states. Cold Spring Harbor Perspectives in Biology 6 pii: a009191. (doi:10.1101/cshperspect.a009191)

Broniowska KA, Mathews CE \& Corbett JA 2013 Do $\beta$-cells generate peroxynitrite in response to cytokine treatment? Journal of Biological Chemistry 288 36567-36578. (doi:10.1074/jbc.M113.522243)

Broniowska KA, Oleson BJ \& Corbett JA $2014 \beta$-Cell responses to nitric oxide. Vitamins and Hormones 95 299-322. (doi:10.1016/B978-0-12 800174-5.00012-0)

Busch AK, Gurisik E, Cordery DV, Sudlow M, Denyer GS, Laybutt DR, Hughes WE \& Biden TJ 2005 Increased fatty acid desaturation and enhanced expression of stearoyl coenzyme A desaturase protects pancreatic $\beta$-cells from lipoapoptosis. Diabetes 54 2917-2924. (doi:10.2337/diabetes.54.10.2917)

Butler AE, Janson J, Bonner-Weir S, Ritzel R, Rizza RA \& Butler PC 2003 $\beta$-Cell deficit and increased $\beta$-cell apoptosis in humans with type 2 diabetes. Diabetes 52 102-110. (doi:10.2337/diabetes.52.1.102)

Cadavez L, Montane J, Alcarraz-Vizan G, Visa M, Vidal-Fabrega L, Servitja JM \& Novials A 2014 Chaperones ameliorate $\beta$ cell dysfunction associated with human islet amyloid polypeptide overexpression. PLoS ONE 9 e101797. (doi:10.1371/journal.pone.0101797)

Calderon B, Carrero JA, Ferris ST, Sojka DK, Moore L, Epelman S, Murphy KM, Yokoyama WM, Randolph GJ \& Unanue ER 2015 The pancreas anatomy conditions the origin and properties of resident macrophages. Journal of Experimental Medicine 212 1497-1512. (doi:10.1084/jem.20150496)

Calfon M, Zeng H, Urano F, Till JH, Hubbard SR, Harding HP, Clark SG \& Ron D 2002 IRE1 couples endoplasmic reticulum load to secretory capacity by processing the XBP-1 mRNA. Nature 415 92-96. (doi:10.1038/415092a)

Cao SS \& Kaufman RJ 2014 Endoplasmic reticulum stress and oxidative stress in cell fate decision and human disease. Antioxidants \& Redox Signaling 21 396-413. (doi:10.1089/ars.2014.5851)

Cardozo AK, Ortis F, Storling J, Feng YM, Rasschaert J, Tonnesen M, Van Eylen F, Mandrup-Poulsen T, Herchuelz A \& Eizirik DL 2005 Cytokines downregulate the sarcoendoplasmic reticulum pump Ca2 + ATPase $2 \mathrm{~b}$ and deplete endoplasmic reticulum $\mathrm{Ca} 2+$, leading to induction of endoplasmic reticulum stress in pancreatic $\beta$-cells. Diabetes 54 452-461. (doi:10.2337/diabetes.54.2.452)

Carpentier A, Mittelman SD, Bergman RN, Giacca A \& Lewis GF 2000 Prolonged elevation of plasma free fatty acids impairs pancreatic $\beta$-cell function in obese nondiabetic humans but not in individuals with type 2 diabetes. Diabetes 49 399-408. (doi:10.2337/diabetes.49.3.399)

Cavelti-Weder C, Furrer R, Keller C, Babians-Brunner A, Solinger AM, Gast H, Fontana A, Donath MY \& Penner IK 2011 Inhibition of IL-1 $\beta$ improves fatigue in type 2 diabetes. Diabetes Care 34 e158. (doi:10.2337/dc11-1196)

Cavelti-Weder C, Babians-Brunner A, Keller C, Stahel MA, Kurz-Levin M, Zayed H, Solinger AM, Mandrup-Poulsen T, Dinarello CA \& Donath MY 2012 Effects of gevokizumab on glycemia and inflammatory markers in type 2 diabetes. Diabetes Care 35 1654-1662. (doi:10.2337/dc11-2219)

Chan JY, Cooney GJ, Biden TJ \& Laybutt DR 2011 Differential regulation of adaptive and apoptotic unfolded protein response signalling by cytokine-induced nitric oxide production in mouse pancreatic $\beta$ cells. Diabetologia 54 1766-1776. (doi:10.1007/s00125-011-2139-z)

Chan JY, Biden TJ \& Laybutt DR 2012 Cross-talk between the unfolded protein response and nuclear factor- $\kappa \mathrm{B}$ signalling pathways regulates cytokine-mediated $\beta$ cell death in MIN6 cells and isolated mouse islets. Diabetologia 55 2999-3009. (doi:10.1007/s00125-012-2657-3)

Chen H, Li X \& Epstein PN 2005 MnSOD and catalase transgenes demonstrate that protection of islets from oxidative stress does not alter cytokine toxicity. Diabetes 54 1437-1446. (doi:10.2337/diabetes. 54.5.1437)

Chen J, Hui ST, Couto FM, Mungrue IN, Davis DB, Attie AD, Lusis AJ, Davis RA \& Shalev A 2008a Thioredoxin-interacting protein deficiency induces Akt/Bcl-xL signaling and pancreatic $\beta$-cell mass and protects against diabetes. FASEB Journal 22 3581-3594. (doi:10.1096/fj.08111690)

Chen J, Saxena G, Mungrue IN, Lusis AJ \& Shalev A 2008b Thioredoxininteracting protein: a critical link between glucose toxicity and $\beta$-cell apoptosis. Diabetes 57 938-944. (doi:10.2337/db07-0715)

Chen J, Fontes G, Saxena G, Poitout V \& Shalev A 2010 Lack of TXNIP protects against mitochondria-mediated apoptosis but not against fatty acid-induced ER stress-mediated $\beta$-cell death. Diabetes 59 440-447. (doi:10.2337/db09-0949)

Chen JJ, Genereux JC \& Wiseman RL 2015 Endoplasmic reticulum quality control and systemic amyloid disease: impacting protein stability from the inside out. IUBMB Life $\mathbf{6 7} 404-413$. (doi:10.1002/iub.1386) 
Cnop M, Ladriere L, Igoillo-Esteve M, Moura RF \& Cunha DA 2010 Causes and cures for endoplasmic reticulum stress in lipotoxic $\beta$-cell dysfunction. Diabetes, Obesity \& Metabolism 12 (Suppl 2) 76-82. (doi:10.1111/j.1463-1326.2010.01279.x)

Cnop M, Foufelle F \& Velloso LA 2012 Endoplasmic reticulum stress, obesity and diabetes. Trends in Molecular Medicine 18 59-68. (doi:10.1016/j.molmed.2011.07.010)

Cobleigh MA \& Robek MD 2013 Protective and pathological properties of IL-22 in liver disease: implications for viral hepatitis. American Journal of Pathology 182 21-28. (doi:10.1016/j.ajpath.2012.08.043)

Coelho DS \& Domingos PM 2014 Physiological roles of regulated Ire1 dependent decay. Frontiers in Genetics 5 76. (doi:10.3389/fgene.2014. 00076)

Collardeau-Frachon S, Vasiljevic A, Jouvet A, Bouvier R, Senee V \& Nicolino M 2014 Microscopic and ultrastructural features in Wolcott-Rallison syndrome, a permanent neonatal diabetes mellitus: about two autopsy cases. Pediatric Diabetes 16 510-520. (doi:10.1111/pedi.12201)

Contreras JL, Smyth CA, Bilbao G, Eckstein C, Young CJ, Thompson JA, Curiel DT \& Eckhoff DE 2003 Coupling endoplasmic reticulum stress to cell death program in isolated human pancreatic islets: effects of gene transfer of Bcl-2. Transplant International 16 537-542. (doi:10.1111/j. 1432-2277.2003.tb00344.x)

Coppieters KT, Dotta F, Amirian N, Campbell PD, Kay TW, Atkinson MA Roep BO \& von Herrath MG 2012 Demonstration of islet-autoreactive CD8 T cells in insulitic lesions from recent onset and long-term type 1 diabetes patients. Journal of Experimental Medicine 209 51-60. (doi:10.1084/jem.20111187)

Cross BC, Bond PJ, Sadowski PG, Jha BK, Zak J, Goodman JM, Silverman RH, Neubert TA, Baxendale IR, Ron D et al. 2012 The molecular basis for selective inhibition of unconventional mRNA splicing by an IRE1binding small molecule. PNAS 109 E869-E878. (doi:10.1073/pnas. 1115623109)

Cunha DA, Hekerman P, Ladriere L, Bazarra-Castro A, Ortis F, Wakeham MC, Moore F, Rasschaert J, Cardozo AK, Bellomo E et al. 2008 Initiation and execution of lipotoxic ER stress in pancreatic $\beta$-cells. Journal of Cell Science 121 2308-2318. (doi:10.1242/jcs.026062)

Das I, Krzyzosiak A, Schneider K, Wrabetz L, D’Antonio M, Barry N, Sigurdardottir A \& Bertolotti A 2015 Preventing proteostasis diseases by selective inhibition of a phosphatase regulatory subunit. Science $\mathbf{3 4 8}$ 239-242. (doi:10.1126/science.aaa4484)

Deng J, Lu PD, Zhang Y, Scheuner D, Kaufman RJ, Sonenberg N, Harding HP \& Ron D 2004 Translational repression mediates activation of nuclear factor $\kappa \mathrm{B}$ by phosphorylated translation initiation factor 2 . Molecular and Cellular Biology 24 10161-10168. (doi:10.1128/MCB.24. 23.10161-10168.2004)

Donath MY 2013 Targeting inflammation in the treatment of type 2 diabetes. Diabetes, Obesity \& Metabolism 15 (Suppl 3) 193-196. (doi:10.1111/dom.12172)

Donath MY, Boni-Schnetzler M, Ellingsgaard H \& Ehses JA 2009 Islet inflammation impairs the pancreatic $\beta$-cell in type 2 diabetes. Physiology 24 325-331. (doi:10.1152/physiol.00032.2009)

Donath MY, Dalmas E, Sauter NS \& Boni-Schnetzler M 2013 Inflammation in obesity and diabetes: islet dysfunction and therapeutic opportunity. Cell Metabolism 17 860-872. (doi:10.1016/j.cmet.2013.05.001)

Doyle ME \& Egan JM 2007 Mechanisms of action of glucagon-like peptide 1 in the pancreas. Pharmacology \& Therapeutics 113 546-593. (doi:10.1016/j.pharmthera.2006.11.007)

Ehses JA, Perren A, Eppler E, Ribaux P, Pospisilik JA, Maor-Cahn R, Gueripel X, Ellingsgaard H, Schneider MK, Biollaz G et al. 2007 Increased number of islet-associated macrophages in type 2 diabetes. Diabetes 56 2356-2370. (doi:10.2337/db06-1650)

Eizirik DL, Miani M \& Cardozo AK 2013 Signalling danger: endoplasmic reticulum stress and the unfolded protein response in pancreatic islet inflammation. Diabetologia 56 234-241. (doi:10.1007/s00125-0122762-3)
Ellingsgaard H, Hauselmann I, Schuler B, Habib AM, Baggio LL, Meier DT, Eppler E, Bouzakri K, Wueest S, Muller YD et al. 2011 Interleukin-6 enhances insulin secretion by increasing glucagon-like peptide-1 secretion from L cells and $\alpha$ cells. Nature Medicine 17 1481-1489. (doi:10.1038/nm.2513)

Elouil H, Bensellam M, Guiot Y, Vander Mierde D, Pascal SM, Schuit FC \& Jonas JC 2007 Acute nutrient regulation of the unfolded protein response and integrated stress response in cultured rat pancreatic islets. Diabetologia 50 1442-1452. (doi:10.1007/s00125-007-0674-4)

Endo M, Mori M, Akira S \& Gotoh T 2006 C/EBP homologous protein (CHOP) is crucial for the induction of caspase-11 and the pathogenesis of lipopolysaccharide-induced inflammation. Journal of Immunology 176 6245-6253. (doi:10.4049/jimmunol.176.10.6245)

Engin F \& Hotamisligil GS 2010 Restoring endoplasmic reticulum function by chemical chaperones: an emerging therapeutic approach for metabolic diseases. Diabetes, Obesity \& Metabolism 12 (Suppl 2) 108-115. (doi:10.1111/j.1463-1326.2010.01282.x)

Engin F, Yermalovich A, Nguyen T, Hummasti S, Fu W, Eizirik DL, Mathis D \& Hotamisligil GS 2013 Restoration of the unfolded protein response in pancreatic $\beta$ cells protects mice against type 1 diabetes. Science Translational Medicine 5 211ra156. (doi:10.1126/scitranslmed.3006534)

Feng D, Park O, Radaeva S, Wang H, Yin S, Kong X, Zheng M, Zakhari S, Kolls JK \& Gao B 2012 Interleukin-22 ameliorates cerulein-induced pancreatitis in mice by inhibiting the autophagic pathway. International Journal of Biological Sciences 8 249-257. (doi:10.7150/ijbs.3967)

Flowers JB, Rabaglia ME, Schueler KL, Flowers MT, Lan H, Keller MP, Ntambi JM \& Attie AD 2007 Loss of stearoyl-CoA desaturase-1 improves insulin sensitivity in lean mice but worsens diabetes in leptin-deficient obese mice. Diabetes 56 1228-1239. (doi:10.2337/db06-1142)

Green CD \& Olson LK 2011 Modulation of palmitate-induced endoplasmic reticulum stress and apoptosis in pancreatic $\beta$-cells by stearoyl-CoA desaturase and Elovl6. American Journal of Physiology. Endocrinology and Metabolism 300 E640-E649. (doi:10.1152/ajpendo.00544.2010)

Gupta S, McGrath B \& Cavener DR 2010 PERK (EIF2AK3) regulates proinsulin trafficking and quality control in the secretory pathway. Diabetes 59 1937-1947. (doi:10.2337/db09-1064)

Gurgul-Convey E, Mehmeti I, Lortz S \& Lenzen S 2011 Cytokine toxicity in insulin-producing cells is mediated by nitro-oxidative stress-induced hydroxyl radical formation in mitochondria. Journal of Molecular Medicine 89 785-798. (doi:10.1007/s00109-011-0747-1)

Gurzov EN, Ortis F, Cunha DA, Gosset G, Li M, Cardozo AK \& Eizirik DL 2009 Signaling by IL- $1 \beta+$ IFN- $\gamma$ and ER stress converge on DP5/Hrk activation: a novel mechanism for pancreatic $\beta$-cell apoptosis. Cell Death and Differentiation 16 1539-1550. (doi:10.1038/cdd.2009.99)

Gurzov EN, Stanley WJ, Brodnicki TC \& Thomas HE 2015 Protein tyrosine phosphatases: molecular switches in metabolism and diabetes. Trends in Endocrinology and Metabolism 26 30-39. (doi:10.1016/j.tem. 2014.10.004)

Han J, Back SH, Hur J, Lin YH, Gildersleeve R, Shan J, Yuan CL, Krokowski D, Wang S, Hatzoglou M et al. 2013 ER-stress-induced transcriptional regulation increases protein synthesis leading to cell death. Nature Cell Biology 15 481-490. (doi:10.1038/ncb2738)

Hara T, Mahadevan J, Kanekura K, Hara M, Lu S \& Urano F 2014 Calcium efflux from the endoplasmic reticulum leads to $\beta$-cell death. Endocrinology 155 758-768. (doi:10.1210/en.2013-1519)

Harding HP, Zhang Y \& Ron D 1999 Protein translation and folding are coupled by an endoplasmic-reticulum-resident kinase. Nature $\mathbf{3 9 7}$ 271-274. (doi:10.1038/16729)

Harding HP, Zyryanova AF \& Ron D 2012 Uncoupling proteostasis and development in vitro with a small molecule inhibitor of the pancreatic endoplasmic reticulum kinase, PERK. Journal of Biological Chemistry 287 44338-44344. (doi:10.1074/jbc.M112.428987)

Hasnain SZ, Lourie R, Das I, Chen AC \& McGuckin MA 2012 The interplay between endoplasmic reticulum stress and inflammation. Immunology and Cell Biology 90 267-270. (doi:10.1038/icb.2011.112) 
Hasnain SZ, Borg DJ, Harcourt BE, Tong H, Sheng YH, Ng CP, Das I, Wang R, Chen AC, Loudovaris T et al. 2014 Glycemic control in diabetes is restored by therapeutic manipulation of cytokines that regulate $\beta$ cell stress. Nature Medicine 20 1417-1426. (doi:10.1038/nm.3705)

Haupt A, Guthoff M, Schafer SA, Kirchhoff K, Machicao F, Gallwitz B, Staiger H, Stefan N, Fritsche A \& Haring HU 2009 The inhibitory effect of recent type 2 diabetes risk loci on insulin secretion is modulated by insulin sensitivity. Journal of Clinical Endocrinology and Metabolism 94 1775-1780. (doi:10.1210/jc.2008-1876)

Hayden MR, Patel K, Habibi J, Gupta D, Tekwani SS, Whaley-Connell A \& Sowers JR 2008 Attenuation of endocrine-exocrine pancreatic communication in type 2 diabetes: pancreatic extracellular matrix ultrastructural abnormalities. Journal of the Cardiometabolic Syndrome $\mathbf{3}$ 234-243. (doi:10.1111/j.1559-4572.2008.00024.x)

Haze K, Yoshida H, Yanagi H, Yura T \& Mori K 1999 Mammalian transcription factor ATF6 is synthesized as a transmembrane protein and activated by proteolysis in response to endoplasmic reticulum stress. Molecular Biology of the Cell 10 3787-3799. (doi:10.1091/mbc.10. 11.3787)

Hill T, Krougly O, Nikoopour E, Bellemore S, Lee-Chan E, Fouser LA, Hill DJ \& Singh B 2013 The involvement of interleukin-22 in the expression of pancreatic $\beta$ cell regenerative Reg genes. Cell Regeneration 22 . (doi:10.1186/2045-9769-2-2)

Hiramatsu N, Messah C, Han J, LaVail MM, Kaufman RJ \& Lin JH 2014 Translational and posttranslational regulation of XIAP by eIF2 $\alpha$ and ATF4 promotes ER stress-induced cell death during the unfolded protein response. Molecular Biology of the Cell 25 1411-1420. (doi:10.1091/mbc.E13-11-0664)

Hollien J, Lin JH, Li H, Stevens N, Walter P \& Weissman JS 2009 Regulated Ire1-dependent decay of messenger RNAs in mammalian cells. Journal of Cell Biology 186 323-331. (doi:10.1083/jcb.200903014)

Hull RL, Zraika S, Udayasankar J, Aston-Mourney K, Subramanian SL \& Kahn SE 2009 Amyloid formation in human IAPP transgenic mouse islets and pancreas, and human pancreas, is not associated with endoplasmic reticulum stress. Diabetologia 52 1102-1111. (doi:10.1007/s00125-009-1329-4)

Igoillo-Esteve M, Marselli L, Cunha DA, Ladriere L, Ortis F, Grieco FA, Dotta F, Weir GC, Marchetti P, Eizirik DL et al. 2010 Palmitate induces a pro-inflammatory response in human pancreatic islets that mimics CCL2 expression by $\beta$ cells in type 2 diabetes. Diabetologia $\mathbf{5 3}$ 1395-1405. (doi:10.1007/s00125-010-1707-y)

Imai Y, Dobrian AD, Morris MA \& Nadler JL 2013 Islet inflammation: a unifying target for diabetes treatment? Trends in Endocrinology and Metabolism 24 351-360. (doi:10.1016/j.tem.2013.01.007)

Ito K, Kiyosawa N, Kumagai K, Manabe S, Matsunuma N \& Yamoto T 2006 Molecular mechanism investigation of cycloheximide-induced hepatocyte apoptosis in rat livers by morphological and microarray analysis. Toxicology 219 175-186. (doi:10.1016/j.tox.2005.11.017)

Itoh Y, Kawamata Y, Harada M, Kobayashi M, Fujii R, Fukusumi S, Ogi K, Hosoya M, Tanaka Y, Uejima $\mathrm{H}$ et al. 2003 Free fatty acids regulate insulin secretion from pancreatic $\beta$ cells through GPR40. Nature $\mathbf{4 2 2}$ 173-176. (doi:10.1038/nature01478)

Jackness C, Karmally W, Febres G, Conwell IM, Ahmed L, Bessler M, McMahon DJ \& Korner J 2013 Very low-calorie diet mimics the early beneficial effect of Roux-en-Y gastric bypass on insulin sensitivity and $\beta$-cell function in type 2 diabetic patients. Diabetes 62 3027-3032. (doi:10.2337/db12-1762)

Jensen MV, Joseph JW, Ronnebaum SM, Burgess SC, Sherry AD \& Newgard CB 2008 Metabolic cycling in control of glucose-stimulated insulin secretion. American Journal of Physiology. Endocrinology and Metabolism 295 E1287-E1297. (doi:10.1152/ajpendo.90604.2008)

Jezek P, Dlaskova A \& Plecita-Hlavata L 2012 Redox homeostasis in pancreatic $\beta$ cells. Oxidative Medicine and Cellular Longevity 2012 932838. (doi:10.1155/2012/932838)

Jiang HY, Wek SA, McGrath BC, Scheuner D, Kaufman RJ, Cavener DR \& Wek RC 2003 Phosphorylation of the $\alpha$ subunit of eukaryotic initiation factor 2 is required for activation of NF- $\kappa B$ in response to diverse cellular stresses. Molecular and Cellular Biology 23 5651-5663. (doi:10.1128/ МСB.23.16.5651-5663.2003)

Julier C \& Nicolino M 2010 Wolcott-Rallison syndrome. Orphanet Journal of Rare Diseases 5 29. (doi:10.1186/1750-1172-5-29)

Jurgens CA, Toukatly MN, Fligner CL, Udayasankar J, Subramanian SL, Zraika S, Aston-Mourney K, Carr DB, Westermark P, Westermark GT et al. $2011 \beta$-Cell loss and $\beta$-cell apoptosis in human type 2 diabetes are related to islet amyloid deposition. American Journal of Pathology 178 2632-2640. (doi:10.1016/j.ajpath.2011.02.036)

Kacheva S, Lenzen S \& Gurgul-Convey E 2011 Differential effects of proinflammatory cytokines on cell death and ER stress in insulinsecreting INS1E cells and the involvement of nitric oxide. Cytokine $\mathbf{5 5}$ 195-201. (doi:10.1016/j.cyto.2011.04.002)

Kaneko M, Niinuma Y \& Nomura Y 2003 Activation signal of nuclear factor- $\mathrm{KB}$ in response to endoplasmic reticulum stress is transduced via IRE1 and tumor necrosis factor receptor-associated factor 2. Biological \& Pharmaceutical Bulletin 26 931-935. (doi:10.1248/bpb.26.931)

Kaneto H \& Matsuoka TA 2015 Role of pancreatic transcription factors in maintenance of mature $\beta$-cell function. International Journal of Molecular Sciences 16 6281-6297. (doi:10.3390/ijms16036281)

Kars M, Yang L, Gregor MF, Mohammed BS, Pietka TA, Finck BN, Patterson BW, Horton JD, Mittendorfer B, Hotamisligil GS et al. 2010 Tauroursodeoxycholic acid may improve liver and muscle but not adipose tissue insulin sensitivity in obese men and women. Diabetes 59 1899-1905. (doi:10.2337/db10-0308)

Keane KN, Cruzat VF, Carlessi R \& de Bittencourt PI Jr 2015 Molecular events linking oxidative stress and inflammation to insulin resistance and $\beta$-cell dysfunction. Oxidative Medicine and Cellular Longevity 2015 181643. (doi:10.1155/2015/181643)

Kim JY, Lim DM, Park HS, Moon CI, Choi KJ, Lee SK, Baik HW, Park KY \& Kim BJ 2012 Exendin-4 protects against sulfonylurea-induced $\beta$-cell apoptosis. Journal of Pharmacological Sciences 118 65-74. (doi:10.1254/ jphs.11072FP)

Kimata Y, Ishiwata-Kimata Y, Ito T, Hirata A, Suzuki T, Oikawa D, Takeuchi M \& Kohno K 2007 Two regulatory steps of ER-stress sensor Ire1 involving its cluster formation and interaction with unfolded proteins. Journal of Cell Biology 179 75-86. (doi:10.1083/jcb.200704166)

Konner AC, Janoschek R, Plum L, Jordan SD, Rother E, Ma X, Xu C, Enriori P, Hampel B, Barsh GS et al. 2007 Insulin action in AgRP-expressing neurons is required for suppression of hepatic glucose production. Cell Metabolism 5 438-449. (doi:10.1016/j.cmet.2007.05.004)

Kumar P, Rajasekaran K, Palmer JM, Thakar MS \& Malarkannan S 2013 IL-22: an evolutionary missing-link authenticating the role of the immune system in tissue regeneration. Journal of Cancer 4 57-65. (doi:10.7150/jca.5048)

Lee MS 2014 Role of islet $\beta$ cell autophagy in the pathogenesis of diabetes. Trends in Endocrinology and Metabolism 25 620-627. (doi:10.1016/j.tem. 2014.08.005)

Lee AH, Iwakoshi NN \& Glimcher LH 2003 XBP-1 regulates a subset of endoplasmic reticulum resident chaperone genes in the unfolded protein response. Molecular and Cellular Biology 23 7448-7459. (doi:10.1128/MCB.23.21.7448-7459.2003)

Lee AH, Heidtman K, Hotamisligil GS \& Glimcher LH 2011 Dual and opposing roles of the unfolded protein response regulated by IRE1 $\alpha$ and XBP1 in proinsulin processing and insulin secretion. PNAS 108 8885-8890. (doi:10.1073/pnas.1105564108)

Lenzen S 2008 Oxidative stress: the vulnerable $\beta$-cell. Biochemical Society Transactions 36 343-347. (doi:10.1042/BST0360343)

Lerner AG, Upton JP, Praveen PV, Ghosh R, Nakagawa Y, Igbaria A, Shen S, Nguyen V, Backes BJ, Heiman M et al. 2012 IRE1 $\alpha$ induces thioredoxininteracting protein to activate the NLRP3 inflammasome and promote programmed cell death under irremediable ER stress. Cell Metabolism 16 250-264. (doi:10.1016/j.cmet.2012.07.007)

Li N, Li B, Brun T, Deffert-Delbouille C, Mahiout Z, Daali Y, Ma XJ, Krause KH \& Maechler P 2012 NADPH oxidase NOX2 defines a new 
antagonistic role for reactive oxygen species and cAMP/PKA in the regulation of insulin secretion. Diabetes 61 2842-2850. (doi:10.2337/ db12-0009)

Lim EL, Hollingsworth KG, Aribisala BS, Chen MJ, Mathers JC \& Taylor R 2011 Reversal of type 2 diabetes: normalisation of $\beta$ cell function in association with decreased pancreas and liver triacylglycerol. Diabetologia 54 2506-2514. (doi:10.1007/s00125-011-2204-7)

Lipson KL, Fonseca SG, Ishigaki S, Nguyen LX, Foss E, Bortell R, Rossini AA $\&$ Urano F 2006 Regulation of insulin biosynthesis in pancreatic $\beta$ cells by an endoplasmic reticulum-resident protein kinase IRE1. Cell Metabolism 4 245-254. (doi:10.1016/j.cmet.2006.07.007)

Liu M, Sun J, Cui J, Chen W, Guo H, Barbetti F \& Arvan P 2015 INS-gene mutations: from genetics and $\beta$ cell biology to clinical disease. Molecular Aspects of Medicine 42 3-18. (doi:10.1016/j.mam.2014.12.001)

Lowell BB \& Shulman GI 2005 Mitochondrial dysfunction and type 2 diabetes. Science 307 384-387. (doi:10.1126/science.1104343)

Luo ZF, Feng B, Mu J, Qi W, Zeng W, Guo YH, Pang Q, Ye ZL, Liu L \& Yuan FH 2010 Effects of 4-phenylbutyric acid on the process and development of diabetic nephropathy induced in rats by streptozotocin: regulation of endoplasmic reticulum stress-oxidative activation. Toxicology and Applied Pharmacology 246 49-57. (doi:10.1016/j.taap. 2010.04.005)

Lynedjian PB 2009 Molecular physiology of mammalian glucokinase. Cellular and Molecular Life Sciences 66 27-42. (doi:10.1007/ s00018-008-8322-9)

Maedler K, Schumann DM, Sauter N, Ellingsgaard H, Bosco D, Baertschiger R, Iwakura Y, Oberholzer J, Wollheim CB, Gauthier BR et al. 2006 Low concentration of interleukin-1 $\beta$ induces FLICE-inhibitory proteinmediated $\beta$-cell proliferation in human pancreatic islets. Diabetes $\mathbf{5 5}$ 2713-2722. (doi:10.2337/db05-1430)

Mahdi T, Hanzelmann S, Salehi A, Muhammed SJ, Reinbothe TM, Tang Y, Axelsson AS, Zhou Y, Jing X, Almgren P et al. 2012 Secreted frizzledrelated protein 4 reduces insulin secretion and is overexpressed in type 2 diabetes. Cell Metabolism 16 625-633. (doi:10.1016/j.cmet.2012. 10.009)

Marchetti P, Bugliani M, Lupi R, Marselli L, Masini M, Boggi U, Filipponi F, Weir GC, Eizirik DL \& Cnop M 2007 The endoplasmic reticulum in pancreatic $\beta$ cells of type 2 diabetes patients. Diabetologia 50 2486-2494. (doi:10.1007/s00125-007-0816-8)

Marciniak SJ, Yun CY, Oyadomari S, Novoa I, Zhang Y, Jungreis R, Nagata K, Harding HP \& Ron D 2004 CHOP induces death by promoting protein synthesis and oxidation in the stressed endoplasmic reticulum. Genes and Development 18 3066-3077. (doi:10.1101/gad. 1250704)

Marhfour I, Lopez XM, Lefkaditis D, Salmon I, Allagnat F, Richardson SJ, Morgan NG \& Eizirik DL 2012 Expression of endoplasmic reticulum stress markers in the islets of patients with type 1 diabetes. Diabetologia 55 2417-2420. (doi:10.1007/s00125-012-2604-3)

Marroqui L, Masini M, Merino B, Grieco FA, Millard I, Dubois C, Quesada I, Marchetti P, Cnop M \& Eizirik DL 2015 Pancreatic $\alpha$ cells are resistant to metabolic stress-induced apoptosis in type 2 diabetes. EBioMedicine 2 378-385. (doi:10.1016/j.ebiom.2015.03.012)

Masters SL, Dunne A, Subramanian SL, Hull RL, Tannahill GM, Sharp FA, Becker C, Franchi L, Yoshihara E, Chen Z et al. 2010 Activation of the NLRP3 inflammasome by islet amyloid polypeptide provides a mechanism for enhanced IL-1 $\beta$ in type 2 diabetes. Nature Immunology 11 897-904. (doi:10.1038/ni.1935)

McKimpson WM, Weinberger J, Czerski L, Zheng M, Crow MT, Pessin JE, Chua SC Jr \& Kitsis RN 2013 The apoptosis inhibitor ARC alleviates the ER stress response to promote $\beta$-cell survival. Diabetes 62 183-193. (doi:10.2337/db12-0504)

Meier DT, Morcos M, Samarasekera T, Zraika S, Hull RL \& Kahn SE 2014 Islet amyloid formation is an important determinant for inducing islet inflammation in high-fat-fed human IAPP transgenic mice. Diabetologia 57 1884-1888. (doi:10.1007/s00125-014-3304-y)
Menge BA, Schrader H, Breuer TG, Dabrowski Y, Uhl W, Schmidt WE \& Meier JJ 2009 Metabolic consequences of a 50\% partial pancreatectomy in humans. Diabetologia 52 306-317. (doi:10.1007/s00125-008-1219-1)

Menu P, Mayor A, Zhou R, Tardivel A, Ichijo H, Mori K \& Tschopp J 2012 ER stress activates the NLRP3 inflammasome via an UPR-independent pathway. Cell Death \& Disease 3 e261. (doi:10.1038/cddis.2011.132)

Merry TL, Tran M, Stathopoulos M, Wiede F, Fam BC, Dodd GT, Clarke I, Watt MJ, Andrikopoulos S \& Tiganis T 2014 High-fat-fed obese glutathione peroxidase 1-deficient mice exhibit defective insulin secretion but protection from hepatic steatosis and liver damage. Antioxidants \& Redox Signaling 20 2114-2129. (doi:10.1089/ ars.2013.5428)

Miani M, Barthson J, Colli ML, Brozzi F, Cnop M \& Eizirik DL 2013 Endoplasmic reticulum stress sensitizes pancreatic $\beta$ cells to interleukin-1 $\beta$-induced apoptosis via Bim/A1 imbalance. Cell Death \& Disease 4 e701. (doi:10.1038/cddis.2013.236)

Miki T, Minami K, Shinozaki H, Matsumura K, Saraya A, Ikeda H, Yamada Y, Holst JJ \& Seino S 2005 Distinct effects of glucose-dependent insulinotropic polypeptide and glucagon-like peptide- 1 on insulin secretion and gut motility. Diabetes 54 1056-1063. (doi:10.2337/ diabetes.54.4.1056)

Montane J, Cadavez L \& Novials A 2014 Stress and the inflammatory process: a major cause of pancreatic cell death in type 2 diabetes. Diabetes, Metabolic Syndrome and Obesity: Targets and Therapy 7 25-34. (doi:10.2147/DMSO.S37649)

Muoio DM \& Newgard CB 2008 Mechanisms of disease: Molecular and metabolic mechanisms of insulin resistance and $\beta$-cell failure in type 2 diabetes. Nature Reviews. Molecular Cell Biology 9 193-205. (doi:10.1038/ nrm2327)

Nakagawa T, Zhu H, Morishima N, Li E, Xu J, Yankner BA \& Yuan J 2000 Caspase-12 mediates endoplasmic-reticulum-specific apoptosis and cytotoxicity by amyloid- $\beta$. Nature 403 98-103. (doi:10.1038/47513)

Nauck MA 2009 Unraveling the science of incretin biology. European Journal of Internal Medicine 20 (Suppl 2) S303-S308. (doi:10.1016/j.ejim. 2009.05.012)

Newsholme P, Rebelato E, Abdulkader F, Krause M, Carpinelli A \& Curi R 2012 Reactive oxygen and nitrogen species generation, antioxidant defenses, and $\beta$-cell function: a critical role for amino acids. Journal of Endocrinology 214 11-20. (doi:10.1530/JOE-12-0072)

Oslowski CM, Hara T, O'Sullivan-Murphy B, Kanekura K, Lu S, Hara M, Ishigaki S, Zhu LJ, Hayashi E, Hui ST et al. 2012 Thioredoxin-interacting protein mediates ER stress-induced $\beta$ cell death through initiation of the inflammasome. Cell Metabolism 16 265-273. (doi:10.1016/j.cmet. 2012.07.005)

Ouyang W, Rutz S, Crellin NK, Valdez PA \& Hymowitz SG 2011 Regulation and functions of the IL-10 family of cytokines in inflammation and disease. Annual Review of Immunology 29 71-109. (doi:10.1146/annurevimmunol-031210-101312)

Oyadomari S, Koizumi A, Takeda K, Gotoh T, Akira S, Araki E \& Mori M 2002 Targeted disruption of the Chop gene delays endoplasmic reticulum stress-mediated diabetes. Journal of Clinical Investigation 109 525-532. (doi:10.1172/JCI0214550)

Ozcan U, Yilmaz E, Ozcan L, Furuhashi M, Vaillancourt E, Smith RO, Gorgun CZ \& Hotamisligil GS 2006 Chemical chaperones reduce ER stress and restore glucose homeostasis in a mouse model of type 2 diabetes. Science 313 1137-1140. (doi:10.1126/science.1128294)

Pahl HL \& Baeuerle PA 1996 Activation of NF- $\kappa$ B by ER stress requires both $\mathrm{Ca} 2+$ and reactive oxygen intermediates as messengers. FEBS Letters 392 129-136. (doi:10.1016/0014-5793(96)00800-9)

Papa FR 2012 Endoplasmic reticulum stress, pancreatic $\beta$-cell degeneration, and diabetes. Cold Spring Harbor Perspectives in Medicine 2 a007666. (doi:10.1101/cshperspect.a007666)

Peiris H, Bonder CS, Coates PT, Keating DJ \& Jessup CF 2014 The $\beta$-cell/EC axis: how do islet cells talk to each other? Diabetes 63 3-11. (doi:10.2337/db13-0617) 
Pineau L \& Ferreira T 2010 Lipid-induced ER stress in yeast and $\beta$ cells: parallel trails to a common fate. FEMS Yeast Research 10 1035-1045. (doi:10.1111/j.1567-1364.2010.00674.x)

Powell DW, Mifflin RC, Valentich JD, Crowe SE, Saada JI, West AB \& Myofibroblasts I 1999 Paracrine cells important in health and disease. American Journal of Physiology 277 C1-C9. (doi:10.1111/j.1469-7793. 1999.001af.x)

Promlek T, Ishiwata-Kimata Y, Shido M, Sakuramoto M, Kohno K \& Kimata Y 2011 Membrane aberrancy and unfolded proteins activate the endoplasmic reticulum stress sensor Ire1 in different ways. Molecular Biology of the Cell 22 3520-3532. (doi:10.1091/mbc.E11-04-0295)

Puthalakath H, O'Reilly LA, Gunn P, Lee L, Kelly PN, Huntington ND, Hughes PD, Michalak EM, McKimm-Breschkin J, Motoyama N et al. 2007 ER stress triggers apoptosis by activating BH3-only protein Bim. Cell 129 1337-1349. (doi:10.1016/j.cell.2007.04.027)

Quan W, Hur KY, Lim Y, Oh SH, Lee JC, Kim KH, Kim GH, Kim SW, Kim HL, Lee MK et al. 2012 Autophagy deficiency in $\beta$ cells leads to compromised unfolded protein response and progression from obesity to diabetes in mice. Diabetologia 55 392-403. (doi:10.1007/s00125-0112350-y)

Rahier J, Guiot Y, Goebbels RM, Sempoux C \& Henquin JC 2008 Pancreatic $\beta$-cell mass in European subjects with type 2 diabetes. Diabetes, Obesity \& Metabolism 10 (Suppl 4) 32-42. (doi:10.1111/j.1463-1326.2008. 00969.x)

Rissanen A, Howard CP, Botha J \& Thuren T 2012 Effect of anti-IL-1 $\beta$ antibody (canakinumab) on insulin secretion rates in impaired glucose tolerance or type 2 diabetes: results of a randomized, placebocontrolled trial. Diabetes, Obesity \& Metabolism 14 1088-1096. (doi:10.1111/j.1463-1326.2012.01637.x)

Rosengren AH, Braun M, Mahdi T, Andersson SA, Travers ME, Shigeto M, Zhang E, Almgren P, Ladenvall C, Axelsson AS et al. 2012 Reduced insulin exocytosis in human pancreatic $\beta$-cells with gene variants linked to type 2 diabetes. Diabetes 61 1726-1733. (doi:10.2337/ db11-1516)

Rutter GA, Pullen TJ, Hodson DJ \& Martinez-Sanchez A 2015 Pancreatic $\beta$-cell identity, glucose sensing and the control of insulin secretion. Biochemical Journal 466 203-218. (doi:10.1042/BJ20141384)

Rutz S, Eidenschenk C \& Ouyang W 2013 IL-22, not simply a Th17 cytokine. Immunological Reviews 252 116-132. (doi:10.1111/imr.12027)

Sabat R, Ouyang W \& Wolk K 2013 Therapeutic opportunities of the IL-22-IL-22R1 system. Nature Reviews. Drug Discovery 13 21-38. (doi:10.1038/nrd4176)

Saliba J, Wattacheril J \& Abumrad NN 2009 Endocrine and metabolic response to gastric bypass. Current Opinion in Clinical Nutrition and Metabolic Care 12 515-521. (doi:10.1097/MCO.0b013e32832e1b14)

Samson SL \& Garber A 2013 GLP-1R agonist therapy for diabetes: benefits and potential risks. Current Opinion in Endocrinology, Diabetes, and Obesity 20 87-97. (doi:10.1097/MED.0b013e32835edb32)

Satoh T, Abiru N, Kobayashi M, Zhou H, Nakamura K, Kuriya G, Nakamura H, Nagayama Y, Kawasaki E, Yamasaki H et al. 2011 CHOP deletion does not impact the development of diabetes but suppresses the early production of insulin autoantibody in the NOD mouse. Apoptosis $\mathbf{1 6}$ 438-448. (doi:10.1007/s10495-011-0576-2)

Scheuner D \& Kaufman RJ 2008 The unfolded protein response: a pathway that links insulin demand with $\beta$-cell failure and diabetes. Endocrine Reviews 29 317-333. (doi:10.1210/er.2007-0039)

Schroder M \& Kaufman RJ 2006 Divergent roles of IRE1 $\alpha$ and PERK in the unfolded protein response. Current Molecular Medicine 6 5-36. (doi:10.2174/156652406775574569)

Seino S, Shibasaki T \& Minami K 2011 Dynamics of insulin secretion and the clinical implications for obesity and diabetes. Journal of Clinical Investigation 121 2118-2125. (doi:10.1172/JCI45680)

Shalev A 2014 Minireview: Thioredoxin-interacting protein: regulation and function in the pancreatic $\beta$-cell. Molecular Endocrinology 28 1211-1220. (doi:10.1210/me.2014-1095)
Shang L, Hua H, Foo K, Martinez H, Watanabe K, Zimmer M, Kahler DJ, Freeby M, Chung W, LeDuc C et al. $2014 \beta$-Cell dysfunction due to increased ER stress in a stem cell model of Wolfram syndrome. Diabetes 63 923-933. (doi:10.2337/db13-0717)

Shioya M, Andoh A, Kakinoki S, Nishida A \& Fujiyama Y 2008 Interleukin 22 receptor 1 expression in pancreas islets. Pancreas 36 197-199. (doi:10.1097/MPA.0b013e3181594258)

Shkoda A, Ruiz P, Daniel H, Kim S, Rogler G, Sartor RB \& Haller DG 2007 Interleukin 10 blocked endoplasmic reticulum stress in intestinal epithelial cells: impact on chronic inflammation. Gastroenterology $\mathbf{1 3 2}$ 190-207. (doi:10.1053/j.gastro.2006.10.030)

Sloan-Lancaster J, Abu-Raddad E, Polzer J, Miller JW, Scherer JC, De Gaetano A, Berg JK \& Landschulz WH 2013 Double-blind, randomized study evaluating the glycemic and anti-inflammatory effects of subcutaneous LY2189102, a neutralizing IL-1 $\beta$ antibody, in patients with type 2 diabetes. Diabetes Care 36 2239-2246. (doi:10.2337/dc12-1835)

Soga T, Ohishi T, Matsui T, Saito T, Matsumoto M, Takasaki J, Matsumoto S, Kamohara M, Hiyama H, Yoshida S et al. 2005 Lysophosphatidylcholine enhances glucose-dependent insulin secretion via an orphan G-protein-coupled receptor. Biochemical and Biophysical Research Communications 326 744-751. (doi:10.1016/j.bbrc.2004.11.120)

Song B, Scheuner D, Ron D, Pennathur S \& Kaufman RJ 2008 Chop deletion reduces oxidative stress, improves $\beta$ cell function, and promotes cell survival in multiple mouse models of diabetes. Journal of Clinical Investigation 118 3378-3389. (doi:10.1172/JCI34587)

Sriburi R, Bommiasamy H, Buldak GL, Robbins GR, Frank M, Jackowski S \& Brewer JW 2007 Coordinate regulation of phospholipid biosynthesis and secretory pathway gene expression in XBP-1(S)-induced endoplasmic reticulum biogenesis. Journal of Biological Chemistry 282 7024-7034. (doi:10.1074/jbc.M609490200)

Sun J, Cui J, He Q, Chen Z, Arvan P \& Liu M 2015 Proinsulin misfolding and endoplasmic reticulum stress during the development and progression of diabetes. Molecular Aspects of Medicine 42 105-118. (doi:10.1016/j. mam.2015.01.001)

Supale S, Li N, Brun T \& Maechler P 2012 Mitochondrial dysfunction in pancreatic $\beta$ cells. Trends in Endocrinology and Metabolism 23 477-487. (doi:10.1016/j.tem.2012.06.002)

Teodoro T, Odisho T, Sidorova E \& Volchuk A 2012 Pancreatic $\beta$-cells depend on basal expression of active ATF6 $\alpha$-p50 for cell survival even under nonstress conditions. American Journal of Physiology. Cell Physiology 302 C992-C1003. (doi:10.1152/ajpcell.00160.2011)

Tersey SA, Nishiki Y, Templin AT, Cabrera SM, Stull ND, Colvin SC, Evans-Molina C, Rickus JL, Maier B \& Mirmira RG 2012 Islet $\beta$-cell endoplasmic reticulum stress precedes the onset of type 1 diabetes in the nonobese diabetic mouse model. Diabetes 61 818-827. (doi:10.2337/db11-1293)

Thorn K, Hovsepyan M \& Bergsten P 2010 Reduced levels of SCD1 accentuate palmitate-induced stress in insulin-producing $\beta$-cells. Lipids in Health and Disease 9 108. (doi:10.1186/1476-511X-9-108)

Thuerauf DJ, Marcinko M, Belmont PJ \& Glembotski CC 2007 Effects of the isoform-specific characteristics of ATF $6 \alpha$ and ATF $6 \beta$ on endoplasmic reticulum stress response gene expression and cell viability. Journal of Biological Chemistry 282 22865-22878. (doi:10.1074/jbc.M701213200)

Tortosa F \& Dotta F 2013 Incretin hormones and $\beta$-cell mass expansion: what we know and what is missing? Archives of Physiology and Biochemistry 119 161-169. (doi:10.3109/13813455.2013.795175)

Toyama H, Takada M, Tanaka T, Suzuki Y \& Kuroda Y 2003 Characterization of islet-infiltrating immunocytes after pancreas preservation by twolayer (UW/perfluorochemical) cold storage method. Transplantation Proceedings 35 1503-1505. (doi:10.1016/S0041-1345(03)00370-1)

Tsunekawa S, Yamamoto N, Tsukamoto K, Itoh Y, Kaneko Y, Kimura T, Ariyoshi Y, Miura Y, Oiso Y \& Niki I 2007 Protection of pancreatic $\beta$-cells by exendin-4 may involve the reduction of endoplasmic reticulum stress; in vivo and in vitro studies. Journal of Endocrinology 193 65-74. (doi:10.1677/JOE-06-0148) 
Uldry M \& Thorens B 2004 The SLC2 family of facilitated hexose and polyol transporters. European Journal of Physiology 447 480-489. (doi:10.1007/ s00424-003-1085-0)

Urano F, Wang X, Bertolotti A, Zhang Y, Chung P, Harding HP \& Ron D 2000 Coupling of stress in the ER to activation of JNK protein kinases by transmembrane protein kinase IRE1. Science 287 664-666. (doi:10.1126/science.287.5453.664)

Uruno A, Yagishita Y \& Yamamoto M 2015 The Keap1-Nrf2 system and diabetes mellitus. Archives of Biochemistry and Biophysics 566 76-84. (doi:10.1016/j.abb.2014.12.012)

Usui M, Yamaguchi S, Tanji Y, Tominaga R, Ishigaki Y, Fukumoto M, Katagiri H, Mori K, Oka Y \& Ishihara H 2012 Atf $6 \alpha$-null mice are glucose intolerant due to pancreatic $\beta$-cell failure on a high-fat diet but partially resistant to diet-induced insulin resistance. Metabolism 61 1118-1128. (doi:10.1016/j.metabol.2012.01.004)

Walker JN, Ramracheya R, Zhang Q, Johnson PR, Braun M \& Rorsman P 2011 Regulation of glucagon secretion by glucose: paracrine, intrinsic or both? Diabetes, Obesity \& Metabolism 13 (Suppl 1) 95-105. (doi:10.1111/j.1463-1326.2011.01450.x)

Walter P \& Ron D 2011 The unfolded protein response: from stress pathway to homeostatic regulation. Science 334 1081-1086. (doi:10.1126/ science.1209038)

Wang Z \& Thurmond DC 2009 Mechanisms of biphasic insulin-granule exocytosis - roles of the cytoskeleton, small GTPases and SNARE proteins. Journal of Cell Science 122 893-903. (doi:10.1242/jcs.034355)

Wang M, Crager M \& Pugazhenthi S 2012 Modulation of apoptosis pathways by oxidative stress and autophagy in $\beta$ cells. Experimental Diabetes Research 2012 article ID 647914. (doi:10.1155/2012/647914)

Wang X, Ota N, Manzanillo P, Kates L, Zavala-Solorio J, Eidenschenk C, Zhang J, Lesch J, Lee WP, Ross J et al. 2014 Interleukin-22 alleviates metabolic disorders and restores mucosal immunity in diabetes. Nature 514 237-241. (doi:10.1038/nature13564)

Wicksteed B, Uchizono Y, Alarcon C, McCuaig JF, Shalev A \& Rhodes CJ 2007 A cis-element in the $5^{\prime}$ untranslated region of the preproinsulin mRNA (ppIGE) is required for glucose regulation of proinsulin translation. Cell Metabolism 5 221-227. (doi:10.1016/j.cmet.2007.02.007)

Xu TY, Chen RH, Wang P, Zhang RY, Ke SF \& Miao CY 2010 4-Phenyl butyric acid does not generally reduce glucose levels in rodent models of diabetes. Clinical and Experimental Pharmacology \& Physiology 37 441-446. (doi:10.1111/j.1440-1681.2009.05328.x)

Xue J, Nguyen DT \& Habtezion A 2012 Aryl hydrocarbon receptor regulates pancreatic IL-22 production and protects mice from acute pancreatitis. Gastroenterology 143 1670-1680. (doi:10.1053/j.gastro.2012.08.051)
Yamazaki H, Hiramatsu N, Hayakawa K, Tagawa Y, Okamura M, Ogata R, Huang T, Nakajima S, Yao J, Paton AW et al. 2009 Activation of the AktNF-кB pathway by subtilase cytotoxin through the ATF6 branch of the unfolded protein response. Journal of Immunology 183 1480-1487. (doi:10.4049/jimmunol.0900017)

Yang C, Diiorio P, Jurczyk A, O'Sullivan-Murphy B, Urano F \& Bortell R 2013 Pathological endoplasmic reticulum stress mediated by the IRE1 pathway contributes to pre-insulitic $\beta$ cell apoptosis in a virus-induced rat model of type 1 diabetes. Diabetologia 56 2638-2646. (doi:10.1007/ s00125-013-3044-4)

Yoshida H, Matsui T, Yamamoto A, Okada T \& Mori K 2001 XBP1 mRNA is induced by ATF 6 and spliced by IRE1 in response to ER stress to produce a highly active transcription factor. Cell 107 881-891. (doi:10.1016/ S0092-8674(01)00611-0)

Yoshioka M, Kayo T, Ikeda T \& Koizumi A 1997 A novel locus, Mody4, distal to D7Mit189 on chromosome 7 determines early-onset NIDDM in nonobese C57BL/6 (Akita) mutant mice. Diabetes 46 887-894. (doi:10.2337/diab.46.5.887)

Yusta B, Baggio LL, Estall JL, Koehler JA, Holland DP, Li H, Pipeleers D, Ling Z \& Drucker DJ 2006 GLP-1 receptor activation improves $\beta$ cell function and survival following induction of endoplasmic reticulum stress. Cell Metabolism 4 391-406. (doi:10.1016/j.cmet.2006.10.001)

Zatyka M, Da Silva Xavier G, Bellomo EA, Leadbeater W, Astuti D, Smith J, Michelangeli F, Rutter GA \& Barrett TG 2015 Sarco(endo)plasmic reticulum ATPase is a molecular partner of Wolfram syndrome 1 protein, which negatively regulates its expression. Human Molecular Genetics 24 814-827. (doi:10.1093/hmg/ddu499)

Zhang P, McGrath B, Li S, Frank A, Zambito F, Reinert J, Gannon M, Ma K, McNaughton K \& Cavener DR 2002 The PERK eukaryotic initiation factor $2 \alpha$ kinase is required for the development of the skeletal system, postnatal growth, and the function and viability of the pancreas. Molecular and Cellular Biology 22 3864-3874. (doi:10.1128/MCB.22.11. 3864-3874.2002)

Zhang W, Feng D, Li Y, Iida K, McGrath B \& Cavener DR 2006 PERK EIF2AK3 control of pancreatic $\beta$ cell differentiation and proliferation is required for postnatal glucose homeostasis. Cell Metabolism 4 491-497. (doi:10.1016/j.cmet.2006.11.002)

Zraika S, Hull RL, Udayasankar J, Aston-Mourney K, Subramanian SL, Kisilevsky R, Szarek WA \& Kahn SE 2009 Oxidative stress is induced by islet amyloid formation and time-dependently mediates amyloidinduced $\beta$ cell apoptosis. Diabetologia 52 626-635. (doi:10.1007/ s00125-008-1255-x)

Received in final form 12 November 2015

Accepted 17 November 2015

Accepted Preprint published online 17 November 2015 http://jme.endocrinology-journals.org DOI: 10.1530/JME-15-0232
(C) 2016 Society for Endocrinology Printed in Great Britain
Published by Bioscientifica Ltd. 